\title{
The spin label amino acid TOAC and its uses in studies of peptides: chemical, physicochemical, spectroscopic, and conformational aspects
}

\author{
Shirley Schreier • José Carlos Bozelli Jr.• \\ Nélida Marín • Renata F. F. Vieira • Clóvis R. Nakaie
}

Received: 23 September 2011 / Accepted: 20 December 2011 /Published online: 21 January 2012

(C) The Author(s) 2012. This article is published with open access at Springerlink.com

\begin{abstract}
We review work on the paramagnetic amino acid 2,2,6,6-tetramethyl-N-oxyl-4-amino-4-carboxylic acid, TOAC, and its applications in studies of peptides and peptide synthesis. TOAC was the first spin label probe incorporated in peptides by means of a peptide bond. In view of the rigid character of this cyclic molecule and its attachment to the peptide backbone via a peptide bond, TOAC incorporation has been very useful to analyze backbone dynamics and peptide secondary structure. Many of these studies were performed making use of EPR spectroscopy, but other physical techniques, such as X-ray crystallography, CD, fluorescence, NMR, and FT-IR, have been employed. The use of doublelabeled synthetic peptides has allowed the investigation of their secondary structure. A large number of studies have focused on the interaction of peptides, both synthetic and biologically active, with membranes. In the latter case, work has been reported on ligands and fragments of GPCR, host defense peptides, phospholamban, and $\beta$-amyloid. EPR studies of macroscopically aligned samples have provided information on the orientation of peptides in membranes. More recent studies have focused on peptide-protein and peptide-nucleic acid interactions. Moreover, TOAC has been
\end{abstract}

This article is dedicated to Professor Antonio C.M. Paiva, who first conceived the use of TOAC for EPR studies of peptides.

S. Schreier $(\bowtie) \cdot$ J. C. Bozelli Jr. N . Marín

Department of Biochemistry, Institute of Chemistry,

University of São Paulo,

São Paulo, Brazil

e-mail: schreier@iq.usp.br

R. F. F. Vieira • C. R. Nakaie

Department of Biophysics, Federal University of São Paulo,

São Paulo, Brazil shown to be a valuable probe for paramagnetic relaxation enhancement NMR studies of the interaction of labeled peptides with proteins. The growth of the number of TOACrelated publications suggests that this unnatural amino acid will find increasing applications in the future.

Keywords TOAC $\cdot$ Spin label $\cdot$ Peptide $\cdot$ Backbone dynamics $\cdot$ Membrane $\cdot$ EPR $\cdot$ Paramagnetic enhanced relaxation

$\begin{array}{ll}\text { Abbreviations } \\ \text { Aib } & \text { Aminoisobutyric acid } \\ \text { Ac6c } & \text { 1-aminocyclohexane-1-carboxylic acid } \\ \text { Afc } & \text { 9-amino-9-fluorenecarboxylic acid } \\ \text { Apo E } & \text { Apolipoprotein E } \\ \text { Bin } & \text { Binaphthyl fluorophore } \\ \text { Boc } & \text { Tert-butyloxycarbonyl } \\ \text { BODIPY } & \text { 4,4-difluoro-4-bora-3a,4a-diaza- } \text {-indacene } \\ \text { Bpa } & \text { 4'-benzoylphenylalanine } \\ \text { CD } & \text { Circular dichroism } \\ \text { cmc } & \text { Critical micelle concentration } \\ \text { CTAB } & \text { N-hexadecyl- } N \text {, } N \text {-trimethylammonium } \\ & \text { bromide } \\ \text { CW } & \text { Continuous wave } \\ \text { DEER } & \text { Double electron-electron resonance } \\ \text { DMPC } & 1,2 \text {-dimiristoyl phosphatidylcholine } \\ \text { DMPG } & \text { 1,2-dimiristoyl phosphatidylglycerol } \\ \text { DOPC } & 1,2 \text {-dioleoyl phosphatidylcholine } \\ \text { DOXYL } & \text { 2,2-dimethyl- } N \text {-oxyl-oxazolidine } \\ \text { DPC } & \text { Dodecylphosphocholine } \\ \text { DPPC } & 1,2 \text {-dipalmitoyl phosphatidylcholine } \\ \text { ED } & \text { Echo detected } \\ \text { EPR } & \text { Electron paramagnetic resonance } \\ \text { ESEEM } & \text { Electron spin echo envelope modulation } \\ & \end{array}$




$\begin{array}{ll}\text { EtOH } & \text { Ethanol } \\ \text { FT-IR } & \text { Fourier-transform infrared } \\ \text { Fmoc } & \text { 9-fluorenylmethyloxycarbonyl } \\ \text { HFIP } & \text { 1,1,1,3,3,3-hexafluoroisopropanol } \\ \text { HPS } & \text { N-hexadecyl- } N \text {, } N \text {-dimethyl-propane sulfonate } \\ \text { LPC } & \text { 1-palmitoyl-2-hydroxy phosphatidylcholine } \\ \text { LPG } & \text { 1-palmitoyl-2-hydroxy phosphatidylglycerol } \\ \text { MAS } & \text { Magic angle spinning } \\ \text { MeOH } & \text { Methanol } \\ \text { MTSSL } & \text { Methanethiosulfonate spin label } \\ \text { NBD } & \text { 7-nitro-1,3-benzoxadiazol-4-yl } \\ \text { Nle } & \text { Norleucine } \\ \text { NMR } & \text { Nuclear magnetic resonance } \\ \text { OtBu } & \text { t-butyl ester } \\ \text { PC } & \text { Phosphatidylcholine } \\ \text { PELDOR } & \text { Pulsed electron-electron double resonance } \\ \text { POAC } & \text { 3-amino-1-oxyl-2,2,5,5-tetramethyl } \\ & \text { pyrrolidine-4-carboxylic acid } \\ \text { POPC } & \text { 1-palmitoyl-2-oleoyl phosphatidylcholine } \\ \text { POPG } & \text { 1-palmitoyl-2-oleoyl phosphatidylglycerol } \\ \text { PRE } & \text { Paramagnetic relaxation enhancement } \\ \text { PROXYL } & \text { 2,2,5,5-tetramethylpirrolidine-1-oxyl } \\ \text { PS } & \text { Phosphatidylserine } \\ \text { SDS } & \text { Sodium dodecyl sulfate } \\ \text { SDSL } & \text { Site-directed spin labeling } \\ \text { SPPS } & \text { Solid phase peptide synthesis } \\ \text { ST } & \text { Saturation transfer } \\ \text { TFE } & \text { Trifluoroethanol } \\ & \end{array}$

\section{Historical data}

In 2011, when we celebrate 30 years since the first publication on the synthesis of TOAC-labeled peptides, we present a brief account of the history of nitroxides and their use as spin labels for studies of the structure and dynamics of biologically relevant molecules and organized systems. The synthesis of nitroxides was first described by Lebedev (Lebedev and Kazarnovskii 1959) and by Hoffmann and Henderson (1961). Nitroxides are extremely interesting from the chemical point of view, since, in contrast with the vast majority of free radicals, that are highly unstable, the -NO group is stable under a variety of physicochemical conditions. This allows the obtaining of their EPR spectra in different solvents, including water, in a range of $\mathrm{pH}$ and temperature. Scientists from the Soviet Union made a great contribution to the development of the chemistry of nitroxides, as well as the knowledge of their physicochemical and spectroscopic properties (see the book by Rozantsev 1970). This contribution has continued until the present days. In France, the group of A. Rassat also reported a great number of studies on the chemistry, physical chemistry, and spectroscopy of nitroxides. The groups of J.F.W. Keana in the
USA and of K. Hideg in Hungary have described the synthesis of a vast number of nitroxide-containing compounds. Computer programs for spectral simulations of spin label spectra have been extensively developed by the group of J.H. Freed in the USA.

In view of the fact that EPR spectroscopy is performed in the microwave range of the electromagnetic spectrum, EPR spectra are very convenient for obtaining information about the motion of molecules, in particular macromolecules. Moreover, EPR spectra are also sensitive to the orientation of molecules with respect to the magnetic field, which renders them very useful for studies of anisotropic systems such as membranes.

The use of nitroxides to obtain conformational information about biological molecules via their EPR spectra was first described by McConnell and coworkers in 1965 in a paper that reported studies of polylysine and bovine serum albumin (Stone et al. 1965). This paper followed the first attempt to introduce a paramagnetic reporter group in an otherwise EPRsilent macromolecule; in this first study, Ohnishi and McConnell (1965) intercalated the chlorpromazine cation radical in a nucleic acid. However, this species was not very stable, pointing to the need for a more convenient reporter group. This role was most adequately performed by the nitroxide group. During the next 15 years, EPR studies of spin-labeled proteins were extensively published. In almost all the studies, proteins were labeled by coupling nitroxide-containing molecules to reactive groups of amino acid side chains, mostly the $-\mathrm{SH}$ group of cysteine. The potentiality of cysteine labeling underwent enormous expansion upon the introduction of SDSL by Hubbell and coworkers (Todd et al. 1989; Altenbach et al. 1989), which brought about the possibility of choosing the residue to be investigated.

Nitroxide spin labels were also used, albeit to a lesser extent, for studies of other macromolecules - nucleic acids and polysaccharides. On the other hand, the EPR spectra of nitroxides have been largely exploited in studies of membranes. The first paper in this field was published by Hubbell and McConnell (1968). Indeed, the EPR spectra of nitroxides were among the first data that provided evidence for molecular motions of lipids in membranesrotation about the long molecular axis (Hubbell and McConnell 1969; Hsia et al. 1970), intramolecular transgauche isomerization (Seelig 1970; Hubbell and McConnell 1971; Schreier-Muccillo et al. 1973), flip-flop (Kornberg and McConnell 1971), and lateral diffusion (Devaux and McConnell 1972; Sackmann and Träuble 1972a, b; Träuble and Sackmann 1972).

In 1981, Nakaie et al. (1981) introduced a new strategy for conformational studies of peptides by means of EPR spectroscopy; in this report, the authors described the use of TOAC (2,2,6,6-tetramethyl-N-oxyl-4-amino-4- 
carboxylic acid), whose synthesis was reported by Rassat and Rey (1967), for the synthesis of peptides where the unnatural spin-labeled amino acid was incorporated for the first time in the chain via a peptide bond. An article focusing on TOAC and its applications appeared in Chemical and Engineering News (Wilson 2000), and a review of work on TOAC-containing peptides was published (McNulty and Millhauser 2002).

\section{Introduction}

When spin labels are bound to an amino acid side chain, their EPR spectra will reflect, in addition to the properties of the backbone, the contribution of side chain flexibility, as well as that of the label molecule itself with respect to the polypeptide backbone. In this context, an interesting alternative to examine the conformational properties of proteins and peptides is the binding of a spin label directly to the backbone. The coupling of TOAC to the peptide chain via a peptide bond was first accomplished by incorporating this $\alpha$-amino acid into model compounds, the peptide hormone angiotensin II, and some of its analogs (Nakaie et al. 1981, 1983).

The SPPS methodology available at the time (Merrifield 1963; Stewart and Young, 1984) relied on the use of the Boc protecting group for the amino group; this approach requires strong acid conditions in the deprotection step, preventing the incorporation of TOAC in internal positions, since the acid treatment causes loss of the paramagnetic group. When the Fmoc-based methodology became available (Atherton and Sheppard 1989; Fields and Noble 1990), Marchetto et al. (1993) published the first report describing the synthesis of angiotensin II analogues labeled with TOAC at internal positions in the peptide chain. It should be mentioned that an attempt to introduce TOAC in a protein by means of genetic engineering was not successful (Cornish et al. 1994), possibly due to steric effects (see below).

The use of TOAC has gained notable expansion, mostly in the study of conformational and dynamical properties of peptides. The group of Glenn L. Millhauser has published a series of papers making use of TOAC's EPR spectra to investigate peptide secondary structure (see "Synthetic peptides"). A major contribution in the field has come from the group of Claudio Toniolo, at the University of Padova. Figure 1 displays the growth of the use of TOAC in the past 15 years. Studies of peptides and other applications, such as the use of TOAC's EPR spectra to monitor the effect of physicochemical conditions on SPPS, will be the object of this review. We intend to cover most of the literature; due to length limitations, the information contained in these papers is presented in a succinct manner.

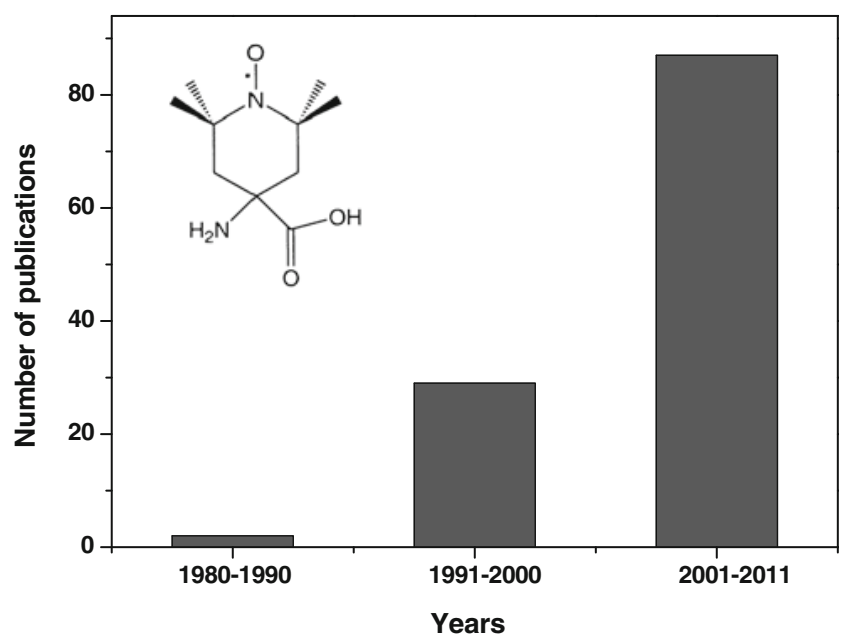

Fig. 1 Structure of TOAC and time evolution of TOAC-related publications

TOAC and TOAC-containing peptides: synthesis and structural, physicochemical, and spectroscopic properties

The synthesis of TOAC was first described by Rassat and Rey (1967). Other nitroxide-derived $\alpha$-amino acids have been synthesized (Lex et al. 1982; Csekö et al. 1985; Balog et al. 2003). A spirocyclohexyl nitroxide $\alpha$-amino acid was synthesized and proposed to be useful for distance measurements by means of pulsed EPR (Rajca et al. 2010). $\alpha$-amino acids have also been synthesized and incorporated in peptides. In an attempt to overcome the low nucleophilicity of TOAC's amino group towards the acylation reaction during peptide chain elongation, Tominaga et al. (2001) described the higher efficiency of incorporation of the $\beta$-amino acid POAC (Rassat and Rey 1967) into angiotensin II. Studies of POAC, as well as of $\beta$-TOAC, have addressed synthesis, separation, identification, spectroscopic characterization, and absolute configuration assignment of pure enantiomers (Wright et al. 2003a, b, 2005, 2008; Péter et al. 2003; Dutot et al. 2008). The synthesis and conformational characterization of hexapeptides double-labeled with $\beta$-TOAC and POAC have also been reported (Wright et al. 2007, 2010). Figure 2 presents the structures of the nitroxide-containing $\alpha$ - and $\beta$-amino acids TOAC, POAC, and $\beta$-TOAC, as well as of the $C^{\alpha, \alpha}$-disubstituted glycines Aib and Ac6c. The former is a non-proteinogenic amino acid present in peptides that display antimicrobial activity.

TOAC is a member of the family of $\mathrm{C}^{\alpha, \alpha}$-disubstituted glycines (Toniolo et al. 1995) characterized by a six-member, heterocyclic, saturated side chain containing the paramagnetic nitroxide radical which is stabilized by the tetrasubstituted carbon atoms 2 and 6. A quantum mechanical study of TOAC in vacuo and in aqueous solution showed that the nitroxyl group in an equatorial position is more stable than in the axial 
<smiles>CC(=O)OC(=O)[C@@]1(N)CC(C)(C)CC1(C)C</smiles>

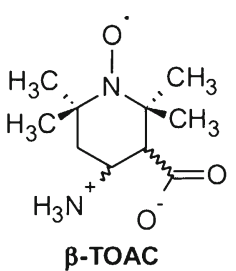

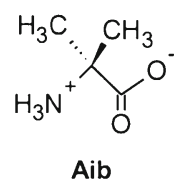

Aib

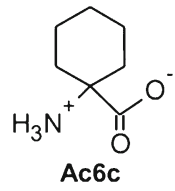

Fig. 2 Chemical structures of the spin-labeled amino acids $T O A C$, $\beta-T O A C$, and $P O A C$ and of the $C^{\alpha, \alpha}$-disubstituted glycines $A i b$ and $A c 6 c$

position (D'Amore et al. 2003). In addition, the crystallographic characterization of some TOAC derivatives showed the piperidine ring in an approximate chair conformation, with the $\alpha$ amino group in the axial position and the $\alpha$-carboxyl group in the equatorial position (Flippen-Anderson et al. 1996; Crisma et al. 2005). The nitroxyl group presents two absorption bands in the UV-visible region, ascribed to the $\mathrm{n} \rightarrow \pi^{*}\left(\Lambda=420-450 \mathrm{~nm}, \varepsilon=5-20 \mathrm{~L} \mathrm{~mol}^{-1} \mathrm{~cm}^{-1}\right)$ and to the $\pi \rightarrow \pi^{*}$ transitions $\left(\kappa \sim 240 \mathrm{~nm}, \varepsilon=10^{3}-10^{4} \mathrm{~L} \mathrm{~mol}^{-1}\right.$ $\left.\mathrm{cm}^{-1}\right)$; the former band is sensitive to solvent polarity (Dupeyre et al. 1964; Brière et al. 1965).

EPR and cyclic voltammetry studies showed that the NO group can undergo reversible redox processes (Toniolo et al. 1995), as well as reversible protonation (Nakaie et al. 1981, 2002; Pertinhez et al. 1997). TOAC-containing peptides were exploited as potential catalysts for enantioselective oxidation (Formaggio et al. 2002). Based on TOAC's redox properties, Gatto et al. (2008) examined the efficiency of peptide-based self-assembled monolayers to mediate electron transfer and photoinduced electron transfer processes on gold substrates.

TOAC-containing model compounds and peptides present high crystallinity allowing for X-ray diffraction studies. Crystallographic studies of synthetic peptides showed that TOAC preferentially adopts helical backbone torsion angles (Toniolo et al. 1995; Flippen-Anderson et al. 1996; Crisma et al. 1997, 2005, 2007; Saviano et al. 2004). These results are in accordance with EPR solution studies (see below) and show that TOAC also induces $3_{10} / \alpha$-helical backbone conformation in the crystal state. These findings are in agreement with the view that members of the family of $C^{\alpha, \alpha}$ disubstituted glycines, such as Aib, Ac6c, and TOAC, favor $\beta$-bends and $3{ }_{10} / \alpha$-helices (Toniolo et al. 1995). X-ray diffraction studies of alanine-based peptides indicated a preference of the piperidine ring for the twist-boat conformation (Flippen-Anderson et al. 1996; Crisma et al. 2005). Crystal studies of TOAC-containing biologically active peptides will be referred to in the corresponding sections.
Making use of the fact that, being paramagnetic, TOAC is a fluorescence quencher, photophysical studies have been performed with peptides containing TOAC and an intrinsic or incorporated fluorophore bound to the same or a different peptide, or to a phospholipid. TOAC was shown to quench the fluorescence of tryptophan, tyrosine, phenylalanine, Bin, Bpa, Fmoc, $\beta$-(1-azulenyl)-L-alanine, BODIPY, and NBD, the two latter attached to phospholipids. References concerning these studies are given in the following sections.

As for EPR spectral properties, like other known nitroxidecontaining molecules, TOAC's spectra are sensitive to the polarity of the environment, the isotropic hyperfine splitting $a_{N}$ decreasing with decreasing polarity. Based on the polarity dependence of $a_{N}$, Malavolta et al. (2008) demonstrated a correlation between $a_{N}$ and a polarity parameter consisting of the sum of solvent electron acceptor (AN) and electron donor (DN) properties $(\mathrm{AN}+\mathrm{DN})$. An alternative polarity scale based on this parameter was proposed as a result of solvation studies of polymers (Cilli et al. 1996; Malavolta et al. 2002). Taking advantage of the sensitivity of $a_{N}$ and $g$ values to the polarity of the environment, Marsh and Toniolo (2008) derived a calibration method to determine the location of TOAC at selected positions in membrane-active peptides. The authors determined the polarity dependence of $a_{N}$ and $g$ for a TOAC-containing dipeptide and for a DOXYLcontaining fatty acid in a range of protic and aprotic media. Correlating these datasets, a polarity profile was established for TOAC in a transmembrane peptide. A similar calibration was deduced for MTSSL, used in protein SDSL.

In contrast to the well-known polarity effects on EPR spectra of nitroxides, a demonstration of the $\mathrm{pH}$-dependence of EPR spectra of nitroxides containing ionizable groups was first presented by Nakaie et al. (1981). Changes in $a_{N}$ in the spectra of TOAC and model TOAC-containing dipeptides yielded titration curves, allowing the accurate determination of the $\mathrm{pK}$ of the ionizable amino and carboxyl groups. It was shown that this resulted from the slow exchange in the EPR timescale between the charged and uncharged species, each yielding a spectrum that contributed to the observed spectrum according to the Henderson-Hasselbalch equation. While the $\mathrm{pK}$ of free TOAC's amino group was 8.0, in TOAC-Gly this value decreased to 5.8. Similar effects were found for N-terminally TOAC-labeled peptides; in addition, $\mathrm{pH}$ modulated conformational changes were also found in these studies (see below).

\section{Synthetic peptides}

The advantage of TOAC over side chain-attached spin labels resides in the fact that the former is linked via a peptide bond; moreover, due to its cyclic structure, the molecule's restricted mobility hampers rotation about side 
chain bonds. In contrast, side chain-attached spin labels lead to higher conformational freedom, rendering the analysis of backbone conformation more difficult. One approach that has been used, especially in the study of synthetic peptides, consists in examining double-labeled peptides. Measurements of spin-spin interactions in the EPR spectra allow the calculation of distances between two TOAC residues in the same peptide chain, and, therefore, the determination of peptide secondary structure (Smythe et al. 1995; Hanson et al. 1996a, b, 1998). For biradicals tumbling fast in the time scale of the experiment, the spectral line shapes are determined primarily by exchange interactions, which are described by the exchange integral J (Luckhurst 1976). In the case of strong exchange, $\mathrm{J} » a_{N}\left(a_{N}\right.$ is the isotropic hyperfine coupling constant), and the spectrum is characterized by a five-line pattern with intensities $1: 2: 3: 2: 1$. In flexible molecules, distance fluctuations between the radicals result in a modulation of $\mathrm{J}$ that can preferentially broaden the second and fourth lines. Biradicals can also exhibit electron-electron dipolar couplings. For fast tumbling peptides, this interaction averages to zero and does not contribute to the EPR spectrum. On the other hand, for molecules tumbling slowly in the EPR time scale (e.g., at low temperature), measurement of dipolar interactions can also yield distances between two labeled residues (Hanson et al. 1996a).
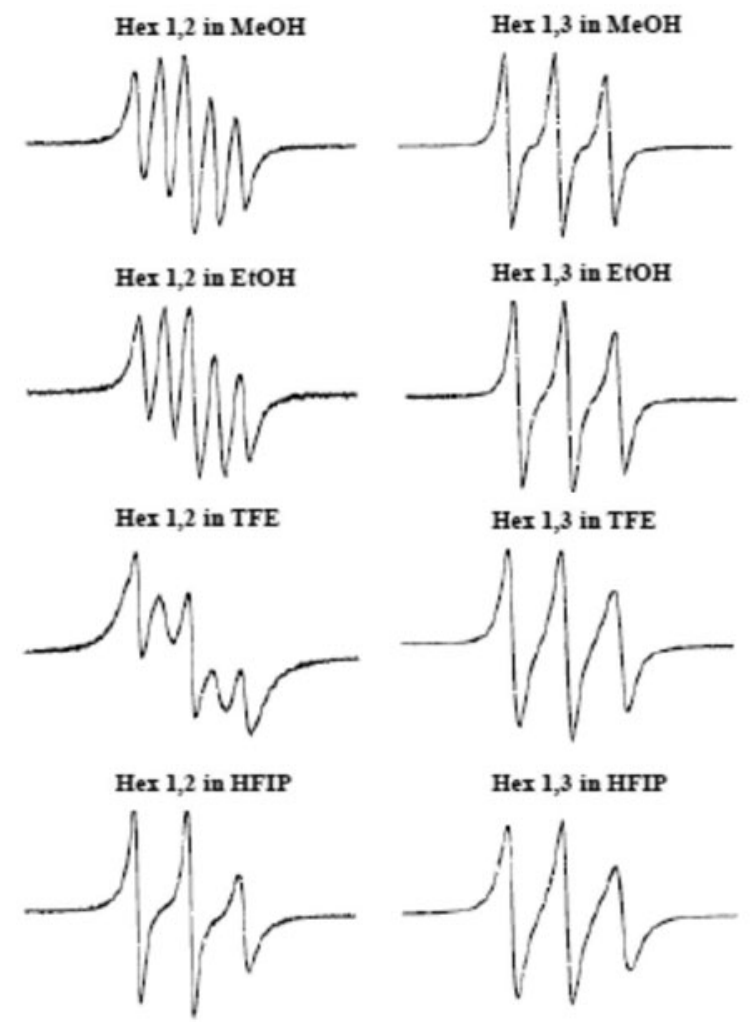

Hex 1,4 in $\mathrm{MeOH}$

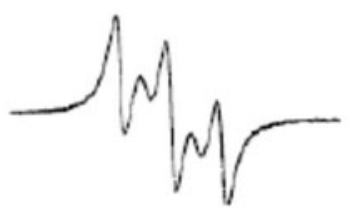

Hex 1,4 in EtOH

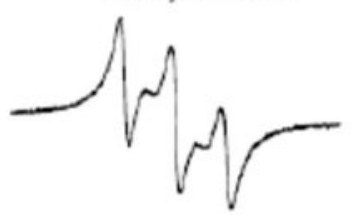

Hex 1,4 in TFE
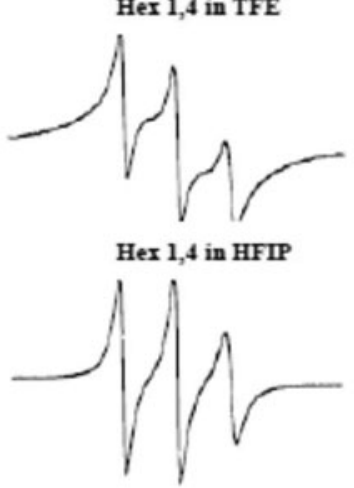

Smythe et al. (1995) examined a 16-residue alaninebased TOAC-double-labeled peptide. The results differed from those previously obtained for a side chain-attached label (Miick et al. 1992), showing that in aqueous solution the peptide acquires $\alpha$-helical and not $3_{10}$-helical conformation. TOAC double-labeling studies of the influence of solvent, chain length, presence of N-terminal blocking groups, and insertion of the strong helix-favoring amino acid Aib showed that these factors affect the backbone geometry of alanine-rich peptides, and also that TOAC is a strong helix stabilizer (Toniolo et al. 1995; Hanson et al. 1996a, b, 1998). Figure 3 presents the EPR spectra of double-labeled hexameric peptides with TOAC in different relative positions as a function of solvent (Hanson et al. 1996a). In $\mathrm{MeOH}$, strong biradical interactions were observed consistent with the geometry of a $30_{10}$-helix. The solvents displayed differing tendencies to support helical structures with the ranking $\mathrm{MeOH}>\mathrm{EtOH}>\mathrm{TFE}>\mathrm{HFIP}$. Spin-spin interaction was also measured in mono- and tri-labeled peptides. Polese et al. (1999) monitored interhelix interaction in mono-labeled $33_{10}$-helical peptides covalently tethered to a cyclo-dipeptide template, and Sartori et al. (2005) showed that the conformational regularity of a linear tri-labeled octapeptide $\left(3_{10}\right.$-helix $)$ is disrupted by an increase in solvent polarity. McNulty et al. (2000) used this methodology to study fold $\rightleftharpoons$ unfold intermediates.

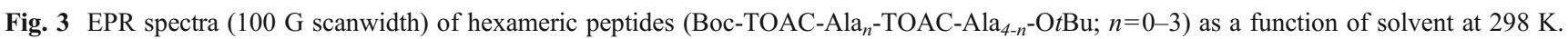
Reprinted from Hanson et al. (1996a), with permission of the American Chemical Society 
Elsäber et al. (2005) performed X-band (at $80 \mathrm{~K}$ ) and Wband (at 80 and $5 \mathrm{~K}$ ) studies to evaluate the relative orientation of two TOAC residues incorporated at different distances in the primary structure of de novo synthesized 15-mer peptides designed to form an $\alpha$-helix. By means of simulations of spectra obtained in different solvents, the authors calculated the distance and relative orientation of the two nitroxides, thus obtaining structural information. The conformations found were solvent-dependent and did not correlate with any of the typical helix types adopted by peptides. Carlotto et al. (2007) and Zerbetto et al. (2007) developed computational approaches to simulate EPR spectra determined by the conformational properties of TOAC-containing peptides.

The combination of different biophysical techniques can provide more complete information on peptide conformational properties. In this context, EPR, CD, fluorescence, FT-IR, NMR, and X-ray crystallography have been used in studies of TOAC-containing peptides. An example is a study of a series of peptides containing the tricyclic $\mathrm{C}^{\alpha, \alpha}$ disubstituted glycine Afc and either TOAC or Gly (Crisma et al. 2000). The results confirmed previous findings showing that Afc may adopt either a fully extended or a turn conformation. In another study, Venanzi et al. (2004) used FTIR, NMR, steady-state and time-resolved fluorescence, and molecular mechanics to investigate constrained hexapeptides containing a fluorescent analogue of tryptophan as well as TOAC.

Although TOAC is an achiral molecule, Bui et al. (2000) explained the unusual far-UV CD spectrum of a TOAC double-labeled hexapeptide that did not correspond to the known elements of secondary structure in terms of a dominating contribution by the peptide-induced $\mathrm{CD}$ of the TOAC $\pi \rightarrow \pi^{*}$ transition. A band was also found in the visible region and was ascribed to TOAC's $n \rightarrow \pi^{*}$ transition. The intensity of this transition could be correlated to peptide conformation. However, in studies with other peptides, TOAC did not seem to disturb the CD spectra of these molecules in the far-UV region (e.g., Schreier et al. 2004; Esposito et al. 2006; Venanzi et al. 2006). Moreover, the NO group does not present any vibrational bands in the amide $\mathrm{A}$, amide I, and amide II regions (Toniolo et al. 1995).

Photophysical studies were also performed, in particular making use of TOAC's fluorescence quenching ability. In cases where the center-to-center TOAC-fluorophore distance was more than $9 \AA$, the quenching mechanism was described as a Förster energy transfer (dipole-dipole interaction) from the excited fluorophore to TOAC, provided the mutual orientation of the fluorophore and TOAC was taken into account (Pispisa et al. 1998; Toniolo et al. 1998, 1999; Pispisa et al. 2000a, b, 2002, 2003a, b). Time-resolved EPR with pulsed laser excitation experiments showed that the intramolecular quenching by $\mathrm{TOAC}$ of a fluorophore in the triplet excited state occurs by enhanced intersystem crossing to the ground state via an electron-exchange process (Corvaja et al. 2000a, b).

\section{Use of TOAC EPR spectra to assess peptide orientation in membranes}

The study of location and orientation of membrane-active peptides upon interaction with membranes is important for the understanding of their mechanism of action at a molecular level. EPR studies of spin-labeled peptides can provide useful information concerning this topic. Due to the fact that TOAC is rigidly attached to the peptide backbone, if the nitroxide orientation is determined in a given system, e.g. in membranes, from the knowledge of TOAC's relative orientation with respect to the axis of the secondary structure, it is possible to obtain information about the orientation of the backbone with respect to the bilayer normal.

Marsh (2006) described a procedure to obtain orientational information about TOAC-containing peptides that acquire $\alpha$-helical and $\beta$-strand conformations in membranes from calculated order parameters. Crystal structure studies of peptides indicated a preference of the TOAC ring for the twist-boat conformation (see "TOAC and TOAC-containing peptides: synthesis and structural, physicochemical, and spectroscopic properties", above). Taking advantage of this information, Marsh derived the tilt of the nitroxide z-axis for both mirror-image twist-boat conformers relative to the $\alpha$ helical and $\beta$-strand axes by building the various TOAC crystal structures into the refined coordinates of $\alpha$-poly-Lalanine and $\beta$-poly-L-alanine structures. The author found that the nitroxide $\mathrm{z}$-axis was inclined at $13 \pm 2$ and $65 \pm$ $3^{\circ}$, with respect to the $\alpha$-helix axis, or at $25 \pm 3$ and $32 \pm$ $3^{\circ}$ with respect to the $\beta$-strand axis, showing that it is possible to use the EPR order parameter to obtain the tilt of TOAC with respect to the bilayer normal; then, making use of the known tilt of the nitroxide z-axis relative to the $\alpha$-helix and $\beta$-strand axes obtained from crystal structures, one can determine the orientation of these axes relative to the bilayer normal. This analysis was applied to TOAC-containing analogues of alamethicin in macroscopically-aligned phospholipid bilayers (see "Alamethicin", below).

An approach to determine the tilt of an $\alpha$-helical TOACcontaining peptide in macroscopically-aligned model membranes based on hyperfine splitting values of the EPR spectra was described by Lorigan and coworkers. In aligned systems, the macroscopic orientation of the bilayer normal with respect to the static magnetic field is known. Then, through the orientation of the nitroxide $\mathrm{z}$-axis with respect to the magnetic field obtained from the hyperfine splittings, it is possible to obtain the orientation of the nitroxide moiety 
with respect to the bilayer normal. Hence, due to the spatial relationship between the nitroxide group and the helix axis (obtained from the crystal structure), it is possible to determine the orientation of the peptide in the membranebound state (Inbaraj et al. 2006). As a model to validate the methodology, Lorigan and collaborators used TOAC-labeled analogues of the nicotinic acetylcholine receptor transmembrane helical domain M2 $\delta$ (EKMSTAISVLLA QAVCLLLTSQR) incorporated into aligned bicelles (Inbaraj et al. 2006), phospholipid bilayer nanotube arrays (Karp et al. 2006), and phospholipid bilayers interfaced between glass plate substrates (Inbaraj et al. 2007). The results yielded a helical tilt angle ranging between $14^{\circ}$ and $16^{\circ}$, compatible with solid-state NMR data, as well as molecular dynamics simulation. Theoretical calculations of hyperfine splitting values derived from EPR spectra of TOAC-labeled $\alpha$-helical M2 $\delta$ in aligned membranes have also been reported (Newstadt et al. 2009).

\section{Biologically active peptides: ligands and fragments of $G$ protein-coupled receptors}

\section{Angiotensin and bradykinin}

The vasoactive peptides angiotensin II (DRVYIHPF, AII) and bradykinin (RPPGFSPFR, BK) bind to G proteincoupled receptors (GPCRs). Studies of these peptides will be presented concomitantly. In the early work by Nakaie et al. (1983), AII analogues containing TOAC at the Nterminus (TOAC ${ }^{0}$-AII and $\mathrm{TOAC}^{1}$-angiotensinamide) were examined by EPR spectroscopy. Solution spectra showed a $\mathrm{pH}$-dependence of peptide conformation, and the analysis of $a_{N}$ yielded a pK of TOAC's amino group around 4.5.

When the methodology to incorporate TOAC in internal positions became available (Marchetto et al. 1993), it was of interest to evaluate the effect of this incorporation on peptide biological activity. This is clearly a concern in the case of biologically active peptides that have a flexible solution conformation, such as small peptide hormones, whose binding to receptors requires the acquisition of very specific conformations. One might expect that incorporation of TOAC - which, in addition to favoring $\alpha$-helical and $310^{-}$ helical conformations, also favors $\beta$-turn formation (Toniolo et al. 1998) - could affect receptor binding and, therefore, biological activity.

Functional studies of AII (TOAC ${ }^{1}$-AII and TOAC $\mathrm{T}^{3}$-AII) and $\mathrm{BK}\left(\mathrm{TOAC}^{0}-\mathrm{BK}\right.$ and $\left.\mathrm{TOAC}^{3}-\mathrm{BK}\right)$ analogues showed that, while N-terminally-labeled peptides retained at least part of their biological activity, internally-labeled analogues were inactive, possibly due to the fact that the TOACimposed bend did not allow acquisition of the receptorbound conformation (Nakaie et al. 2002; Santos et al. 2008).
In order to obtain more detailed information and compare the conformational properties of TOAC-containing analogues to those of native peptides, in addition to EPR, CD and fluorescence studies were performed in solution (as a function of $\mathrm{pH}$ and of addition of the secondary structureinducing solvent TFE) and in the presence of model membranes (micelles and phospholipid bilayer vesicles of variable composition). Studies with model membranes were performed in view of the Membrane Compartment Theory (Schwyzer 1995), which proposes that, once bound, the peptide concentration increases in the membrane phase and it diffuses bidimensionally, increasing the probability of interacting with the receptor. Furthermore, binding to the membrane might displace the peptide conformational equilibrium, favoring acquisition of the receptor-bound conformation.

Schreier et al. (2004) showed that the EPR spectra of $\mathrm{TOAC}^{1}$-AII and $\mathrm{TOAC}^{0}$-BK were sensitive to the $\mathrm{pH}$ titration of TOAC's amino group ( $a_{N}$ values and rotational correlation times, $\tau_{\mathrm{C}}$ ). Moreover, the rotational correlation times of peptides labeled at position 3 were considerably larger than those of $\mathrm{N}$-terminally-labeled peptides, evincing the greater freedom of motion at the $\mathrm{N}$-terminus. CD spectra of N-terminally labeled analogues indicated a flexible backbone and, in most cases, were similar to those of native peptides; in contrast, spectra of peptides containing TOAC at position 3 suggested a more restricted conformation. Furthermore, TOAC caused quenching of $\mathrm{Tyr}^{4}$ fluorescence, which was more intense in the case of $\mathrm{TOAC}^{3}$-AII due to the closer proximity of the nitroxide.

TFE caused a considerable increase in $\tau_{\mathrm{C}}$ values. It was concluded that EPR spectra monitored both the increased solvent viscosity and the peptide's acquisition of secondary structure. CD spectra showed that the native peptides and the N-terminally-labeled analogues acquired similar conformations. On the other hand, different folds were achieved by $\mathrm{TOAC}^{3}$-AII and $\mathrm{TOAC}^{3}$-BK. In the latter case, comparison with the $\mathrm{Aib}^{3}$-BK analogue (Cann et al. 1987) showed that the spectra of both peptides are very similar, demonstrating that both residues indeed impose a similar bend (different from that promoted by the Pro residue in the native peptide), even in non-helical peptides. It was proposed that the conformational behavior provides an explanation for the lack of biological activity of TOAC ${ }^{3}-\mathrm{AII}$ and $\mathrm{TOAC}^{3}-\mathrm{BK}$.

Combined EPR and CD studies were also performed on the interaction of BK (Vieira et al. 2002) and AII (Vieira et al. 2009) and their TOAC-labeled analogues with detergent micelles-negatively charged SDS and zwitterionic HPS. Line broadening in the EPR spectra indicated micelle binding (Fig. 4). The peptides bound to a much greater extent to negatively charged SDS, pointing to the importance of electrostatic interactions. Nevertheless, binding to HPS could still be detected, suggesting that other interactions (hydrophobic, hydrogen bonding, van der Waals interactions) contributed to 


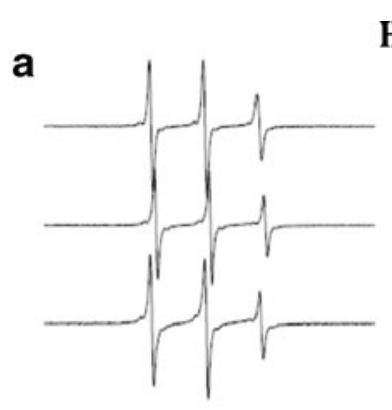

HPS
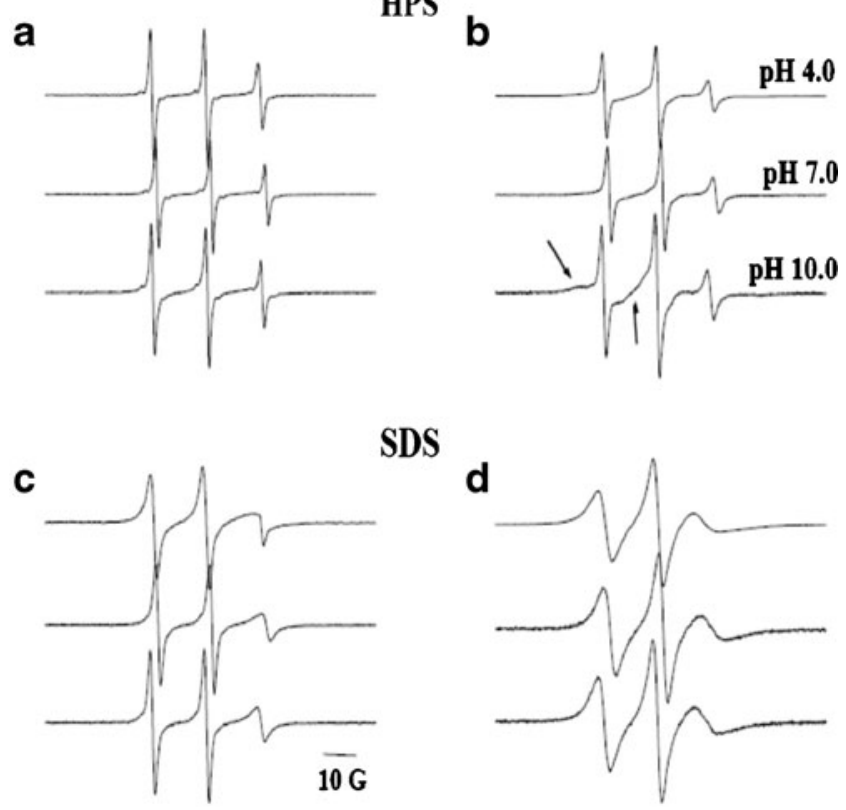

SDS

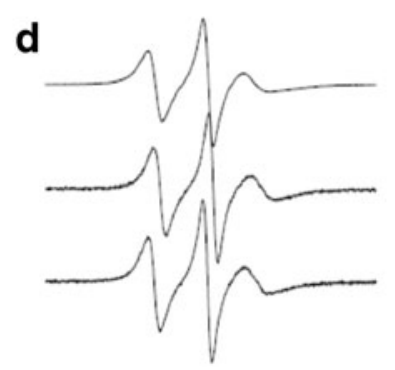

Fig. 4 EPR spectra of $0.1 \mathrm{mM} \mathrm{TOAC}^{1}$-AII $(\mathbf{a}, \mathbf{c})$ and $\mathrm{TOAC}^{3}$-AII $(\mathbf{b}, \mathbf{d})$ in the presence of $50 \mathrm{mM}$ HPS $(\mathbf{a}, \mathbf{b})$ and SDS (c, d) in $15 \mathrm{mM}$ phosphate-borate-citrate buffer at $\mathrm{pH} 4.0$ (top), 7.0 (middle), 10.0 (bottom). The arrows in the spectrum of TOAC ${ }^{3}$-AII in the presence of HPS at $\mathrm{pH} 10.0$ indicate an immobilized component due to HPS-bound TOAC $^{3}$-AII. Reprinted from Vieira et al. (2009) with permission of John Wiley \& Sons

the energetics of binding. The small decrease of $a_{N}$ values suggested a membrane-water interface location for the peptides. Upon binding, the peptides acquired secondary structure, evincing that the less polar membrane environment favors intramolecular hydrogen bonding. The acquired conformations followed a pattern similar to that previously found, i.e., the N-terminally-labeled peptides acquired conformations similar to those of the native peptides, whereas those labeled at position 3 acquired different folds. Both EPR and CD spectra indicated that, upon binding, the peptides underwent $\mathrm{pH}$-dependent conformational changes. Binding caused an increase of fluorescence of AII and its analogues. The differences in conformation achieved by the native and N-terminally-labeled peptides versus those labeled at position 3 corroborated the proposal that the lack of biological activity of the latter is related to the TOAC-imposed bend in these peptides.

In more recent work, Marín (2007) and Marín et al. (2011) examined the interaction of the same peptides with micelles of LPC or 1:1 mol:mol LPC:LPG, as well as with vesicles of POPC or 1:1 mol:mol POPC:POPG. In addition to $\mathrm{CD}$ and EPR, fluorescence measurements of $\mathrm{Tyr}^{4}$ in AII and of $\mathrm{Phe}^{5}$ and $\mathrm{Phe}^{8}$ in $\mathrm{BK}$ were performed. Again, the peptides bound to a much lesser extent to zwitterionic than to negatively charged membranes, binding being more pronounced at lower $\mathrm{pH}$ (when the peptides carry higher positive charge), corroborating the role of electrostatic interactions for binding. Quantitation of free and membrane-bound peptide populations in the EPR spectra allowed calculation of partition coefficients. Differential quenching by TOAC ${ }^{1}$-AII of the fluorescence of phospholipids carrying NBD at different positions corroborated the notion that the peptide is located at the membrane-water interface.

Teixeira et al. (2007) examined the effect of TOAC incorporation on the cleavage of analogues of the AII precursor, angiotensin I (DRVYIHPFHL, AI) by the angiotensinconverting enzyme (ACE). Biological assays showed that the enzyme was selective with respect to labeling position, cleaving only $\mathrm{TOAC}^{1}-\mathrm{AI}$ and $\mathrm{TOAC}^{3}-\mathrm{AI}$. The lack of activity towards $\mathrm{TOAC}^{8}-\mathrm{AI}$ and $\mathrm{TOAC}^{9}-\mathrm{AI}$ indicated that sterical hindrance at the $\mathrm{C}$-terminus probably does not allow substrate binding to the active site. Differences in EPR spectral lineshapes of TOAC ${ }^{3}$-labeled peptides were sufficient to allow the distinction between the substrate and the product. Quenching of $\mathrm{Tyr}^{4}$ fluorescence by TOAC decreased with increasing distance between both residues, suggesting an overall partly extended conformation of AI.

Lopes and collaborators (2008) described a novel EPR approach to evaluate the binding site of AII to its transmembrane $\mathrm{AT}_{1}$ receptor. The authors used a biologically active agonist (TOAC ${ }^{1}$-AII) and an inactive control (TOAC ${ }^{4}$-AII) to assess the peptides interaction with fragments of AII's $\mathrm{AT}_{1}$ receptor in solution. EPR spectra showed that TOAC ${ }^{1}$ AII, but not $\mathrm{TOAC}^{4}$-AII was able to interact with a proposed binding site composed of portions of the receptor $\mathrm{N}$ terminal domain (residues 13-17) and the third extracellular loop (residues 266-278). A study using the same experimental design was done for the interaction of BK with its B2 receptor (Duarte et al. 2011).

\section{$\alpha$-melanocyte stimulating hormone, $\alpha$-MSH}

The N-terminally-labeled analogue of $\alpha$-melanocyte stimulating hormone (Ac-SYSMEHFRWGKPV, $\alpha-\mathrm{MSH}, \mathrm{Ac}=$ acetyl) was the first TOAC-labeled hormone (Ac-TOAC ${ }^{0}$ $\alpha-\mathrm{MSH}$ ) that retained full biological activity (Barbosa et al. 1999). Subsequently, Nakaie et al. (2001) showed that the TOAC-containing derivative of the more potent $\alpha$-MSH analogue $\left[\mathrm{Nle}^{4}, \mathrm{D}-\mathrm{Phe}^{7}\right] \alpha-\mathrm{MSH}\left(\mathrm{Ac}^{-T O A C}{ }^{0}-\left[\mathrm{Nle}^{4}, \mathrm{D}-\right.\right.$ $\left.\mathrm{Phe}^{7}\right] \alpha$-MSH), was also fully active. Solution EPR spectra yielded rotational correlation times indicative of a slightly more folded structure for Ac-TOAC ${ }^{0}-\left[\mathrm{Nle}^{4}, \mathrm{D}-\mathrm{Phe}^{7}\right] \alpha-$ MSH than for Ac-TOAC ${ }^{0}-\alpha-\mathrm{MSH}$. This was corroborated by TOAC quenching of $\operatorname{Trp}^{9}$ fluorescence and by timeresolved fluorescence data (Nakaie et al. 2001; Fernandez et al. 2005b). Acid-base titration of the peptides was also monitored by EPR and time-resolved fluorescence (Fernandez et al. 2005b). Although the latter technique allowed the $\mathrm{pK}$ determination of several side chains, the EPR spectra were 
only slightly $\mathrm{pH}$-dependent, probably because the TOAC amino group was not titrated since it was blocked by the acetyl radical.

EPR and time-resolved fluorescence were also used to investigate the interaction between the TOAC-labeled peptides and DMPG (Fernandez et al. 2005a). EPR spectra showed that both peptides displayed similar, strongly restricted motion, indicating insertion into the membrane, both in the gel and in the liquid crystalline phases. $a_{N}$ values showed nitroxide incorporation, albeit not deeply into the bilayer core. Accordingly, time-resolved fluorescence data indicated that the membrane-bound native peptides, as well as their TOAC derivatives, presented similar conformations. Calculation of partition coefficients $(\mathrm{P})$ from free and bound peptide populations in the EPR spectra showed a $\mathrm{pH}$-dependence of $\mathrm{P}$ with a $\mathrm{pK}$ of ca. 7.5, which was ascribed to the titration of $\mathrm{His}^{6}$.

\section{Neuropeptide Y, NPY}

Neuropeptide Y (YPSKPDNPGEDAPAEDLARYYSALR HYINLITRQRY-NH$H_{2}$, porcine NPY), one of the most abundant peptides in mammalian central nervous system, binds to at least five GPCRs $-\mathrm{Y}_{1}, \mathrm{Y}_{2}, \mathrm{Y}_{4}, \mathrm{Y}_{5}$ and $\mathrm{Y}_{6}$. NPY analogues containing TOAC at positions 2, 32, and 34 were synthesized (Bettio et al. 2002). While [TOAC $\left.{ }^{34}\right]$-NPY and $\left[\mathrm{Ala}^{31}, \mathrm{TOAC}^{32}\right]$-NPY showed a marked selectivity for $\mathrm{Y}_{5}$, the specific binding of [TOAC $\left.{ }^{2}\right]-\mathrm{NPY}$ to $\mathrm{Y}_{2}$ and $\mathrm{Y}_{5}$ was in the same range as that of native NPY; however, the peptide was inactive at $\mathrm{Y}_{1}$. The data indicated that TOAC introduction in the $\mathrm{N}$-terminal region is better tolerated than in proximity to the $\mathrm{C}$-terminus. The effect of TOAC on the native peptide structure was examined by $\mathrm{CD}$. The spectra were interpreted in terms of an increased $\alpha$-helical content in $\left[\mathrm{TOAC}^{34}\right]$-NPY. EPR spectra of the labeled peptides showed that NPY interacts with PS vesicles through the C-terminal $\alpha$-helix, while the $\mathrm{N}$ terminal tail retains flexibility comparable to that in solution. Thomas et al. $(2005,2009)$ investigated the interaction of the TOAC-labeled peptides with model membranes consisting of variable proportions of PC:PS making use of EPR and NMR, as well as fluorescence. The EPR data were analyzed in terms of three peptide populations: free, dimerized, and membranebound. In order to obtain the spectra of the membrane-bound population, potassium chromium oxalate was used to broaden the EPR lines due to peptide free in solution. The presence of free and bound peptide spectra allowed the estimation of partition coefficients, which displayed a $\mathrm{pH}$ dependence. The depth of membrane penetration was also evaluated by ${ }^{1}$ H NMR MAS experiments. TOAC-promoted PRE depended on its distance from specific phospholipid hydrogens. In spite of the broad distribution of the PRE effect due to the high mobility of both lipid and peptide, the results corroborated the EPR-based conclusions showing that the $\alpha$-helical part of
NPY (amino acids 13-36) penetrates the membrane interface, while the unstructured N-terminal part (amino acids 1-12) extends into the aqueous phase with occasional contacts with the headgroup region. The results also suggested that NPY's immersion depth is modulated by membrane composition: the NPY $\alpha$-helix is located in the upper chain region of zwitterionic membranes, being shifted to the glycerol region in negatively charged membranes. In PC:PS membranes, an intermediate position was observed. Finally, membrane location was also verified by fluorescence quenching experiments with the $\operatorname{Trp}^{32}$-NPY analogue. It was concluded that electrostatic interactions play an important role in peptide binding.

\section{Substance P, SP}

Shafer et al. (2008) reported a study where substance P (RPKPQQFFGLM-NH2, SP) was labeled with TOAC at positions 4 or 9 and the affinity of the analogues for the neurokinin-1 receptor was compared to that of native SP. While the binding of $\mathrm{TOAC}^{4}$-SP resembled that of the native ligand, $\mathrm{TOAC}^{9}-\mathrm{SP}$ bound to a much lesser extent. Moreover, the signaling potency of TOAC ${ }^{4}$-SP was higher than that of SP itself; in contrast, the potency of position 9labeled analogue was significantly reduced. EPR spectra reported on these differences. Both peptides gave rise to spectra that indicated restricted mobility in the presence of membranes containing over-expressed receptor. However, while $\mathrm{TOAC}^{4}$-SP bound under conditions of low or high receptor activity, a bound signal for $\mathrm{TOAC}^{9}$-SP was only obtained when the receptor was in the high-affinity binding state. Molecular dynamics calculations showed that the residue replacing $\mathrm{Pro}^{4}$ is located at the beginning of an existing helix and does not disturb the flexibility of the $\mathrm{N}$ terminal sequence ("the address sequence"), while maintaining the helical conformation of the following residues. On the other hand, when TOAC replaces Gly ${ }^{9}$ in the C-terminal portion ("message domain"), while the peptide also stabilizes in the left-handed helical conformation, it is able to adopt $\beta$ sheet conformations, not available in the native peptide.

\section{A TOAC-labeled fragment of the mas oncogene receptor}

The hypothesis that protein fragments are able to acquire the same conformation they display in the whole molecule has been verified in many cases. Based on this hypothesis, an $\mathrm{N}$ terminally-TOAC-labeled fragment of the mas oncogene receptor (EYWSTFGNLHHISL, residues 253-266) encompassing part of the third extracellular loop and the beginning of the seventh transmembrane portion was synthesized, and its interaction with differently charged bilayers and micelles was investigated. EPR spectra showed that, while binding to micelles occurred irrespective of detergent headgroup and 
charge, no interaction took place with bilayers unless peptide and phospholipid bore opposite charges. Thus, while the peptide bound to negatively charged SDS, positively charged CTAB, zwitterionic LPC and HPS, and neutral Brij35 micelles, it interacted with DMPG vesicles only at low $\mathrm{pH}$, both in the gel and in the liquid crystalline phase. CD and steady-state fluorescence measurements corroborated these findings (Pertinhez-Sini et al. 1994; Pertinhez et al. 1995, 1997). Partition coefficients were calculated from the estimation of free and membrane-bound populations in the peptide EPR spectra.

\section{Biologically active peptides: host defense peptides}

Host defense peptides (HDP) or antimicrobial peptides (AMP) present a wide action spectrum against pathogenic microorganisms, being considered an alternative to conventional antibiotics (Zasloff 2002; Brogden 2005). TOAC labeling has been used to gather information about the structure and dynamics of these peptides. In studies of trichogin GA IV (see "Trichogin GA IV") and alamethicin F50/5 (see "Alamethicin"), the authors have taken advantage of the fact that TOAC structurally resembles Aib present in the native peptides.

\section{Trichogin GA IV}

A great deal of the present understanding of the structure and dynamic properties of the Aib-rich linear peptaibol trichogin GA IV (nOctUGLUGGLUGILol; nOct = n-octanoyl, $\mathrm{U}=$ Aib, Lol = leucinol) has been obtained through studies of analogues where Aib residues have been substituted by TOAC. Since both residues are helix-inducing moieties, one would expect that this substitution would not perturb the peptide conformation (and function) to a significant extent. Indeed, mono- and double-substitution of residues 1, 4, and 8 revealed that the analogues have membrane-modifying properties comparable to those of the native peptide (Epand et al. 1999; Monaco et al. 1999a, b). ED-EPR spectra indicated that TOAC at positions 1 and 8 is more flexible than at position 4 (Toropov et al. 1998).

X-ray diffraction studies showed that, like the native peptide (Toniolo et al. 1994), in the crystal state the TOAC-labeled analogues fold as a right-handed, mixed $3_{10} / \alpha$-helix (Crisma et al. 1997; Monaco et al. 1999a; Saviano et al. 2004). Figure 5 shows the structures of two crystallographically independent molecules ( $a$ and $b$ ) in the asymmetric unit of the $\mathrm{TOAC}^{4,8}$-trichogin analogue. In solution, EPR studies of single- and double-labeled peptides showed that the secondary structure remains essentially unchanged when compared to the crystal state (Anderson et al. 1999; Monaco et al. 1999a). The N-terminus adopts a $310^{-}$ helical structure and the C-terminus is partially folded in an $\alpha$-helical conformation, also presenting an equilibrium with unfolded conformers. Anderson et al. (1999) suggested that the Gly-Gly stretch creates a hinge point between two short, but stable helical regions. Furthermore, PELDOR studies were performed to assess the conformation of TOAC-containing analogues when doped in a tetrameric supramolecular assembly of unlabeled peptides (Milov et al. 2001a), of dimers in frozen glassy solutions (Milov et al. 2004), and upon interaction with bilayers (Milov et al. 2005a, b). These results also showed the presence of a mixture of $3_{10} / \alpha$-helical structure. Far-UV $\mathrm{CD}$ spectra corroborated the helical structure of these analogues (Venanzi et al. 2006).

The self-aggregation properties of TOAC-labeled trichogin GA IV analogues were studied mostly by Milov et al. (2000a, b, 2001b, 2002, 2003a, b) using PELDOR combined with conventional CW-EPR. While formation of aggregates containing four peptide molecules was seen in an apolar solvent at $77 \mathrm{~K}$, addition of a more polar solvent led to aggregate dissociation. In weakly polar solvents at $77 \mathrm{~K}$, aggregation $(n=3.1-4.3$ molecules) was dependent on the type of N-terminal group and TOAC position in the peptide chain, as well as solvent composition (Milov et al. 2000a). Tetramers also formed in solvents of different polarity at room temperature (Milov et al. 2000a, 2001b). In addition, in an apolar solvent, the analogues gave rise to concentration-dependent twocomponent EPR spectra, one ascribed to monomers and the other to aggregates (Milov et al. 2003a). Moreover, a study of self-aggregation properties of mono- and double-labeled TOAC analogues of two head-to-tail, covalently linked trichogin GA IV molecules was also performed (Milov et al. 2003b). PELDOR and CW-EPR studies in frozen glassy solutions showed that, while the covalent dimer does not form aggregates in methanol, in chloroform-toluene aggregates $(n=2-3)$ were observed. Aggregation of TOACcontaining trichogin GA IV was not detected in membranes of the bacterium Micrococcus luteus (Milov et al. 2002), but was found in model membranes when the peptide:lipid ratio was high (mean aggregation number=2) (Salnikov et al. 2006). EPR and fluorescence studies showed that, upon interaction with the membrane, at low peptide:lipid ratio the peptides acquired an in-plane orientation on the membrane surface, while at higher peptide:lipid ratios, the orientation changed to a transmembrane arrangement (Epand et al. 1999; Monaco et al. 1999b; Salnikov et al. 2006). In addition, an ED-EPR study showed that the peptides presented two types of orientational motion: at low peptide:lipid ratio, the spectrum indicated fast (nanosecond timescale) motion, whereas upon increasing peptide:lipd ratio, slow (millisecond timescale) motion was observed (Syryamina et al. 2010). 
Fig. 5 X-ray diffraction structures of the two crystallographically independent molecules $\mathbf{a}$ and $\mathbf{b}$ in the asymmetric unit of the $\mathrm{TOAC}^{4,8}$-trichogin analogue with atom numbering. The intramolecular H-bonds are indicated by dashed lines. Reprinted from Monaco et al. (1999a) with permission of John Wiley \& Sons
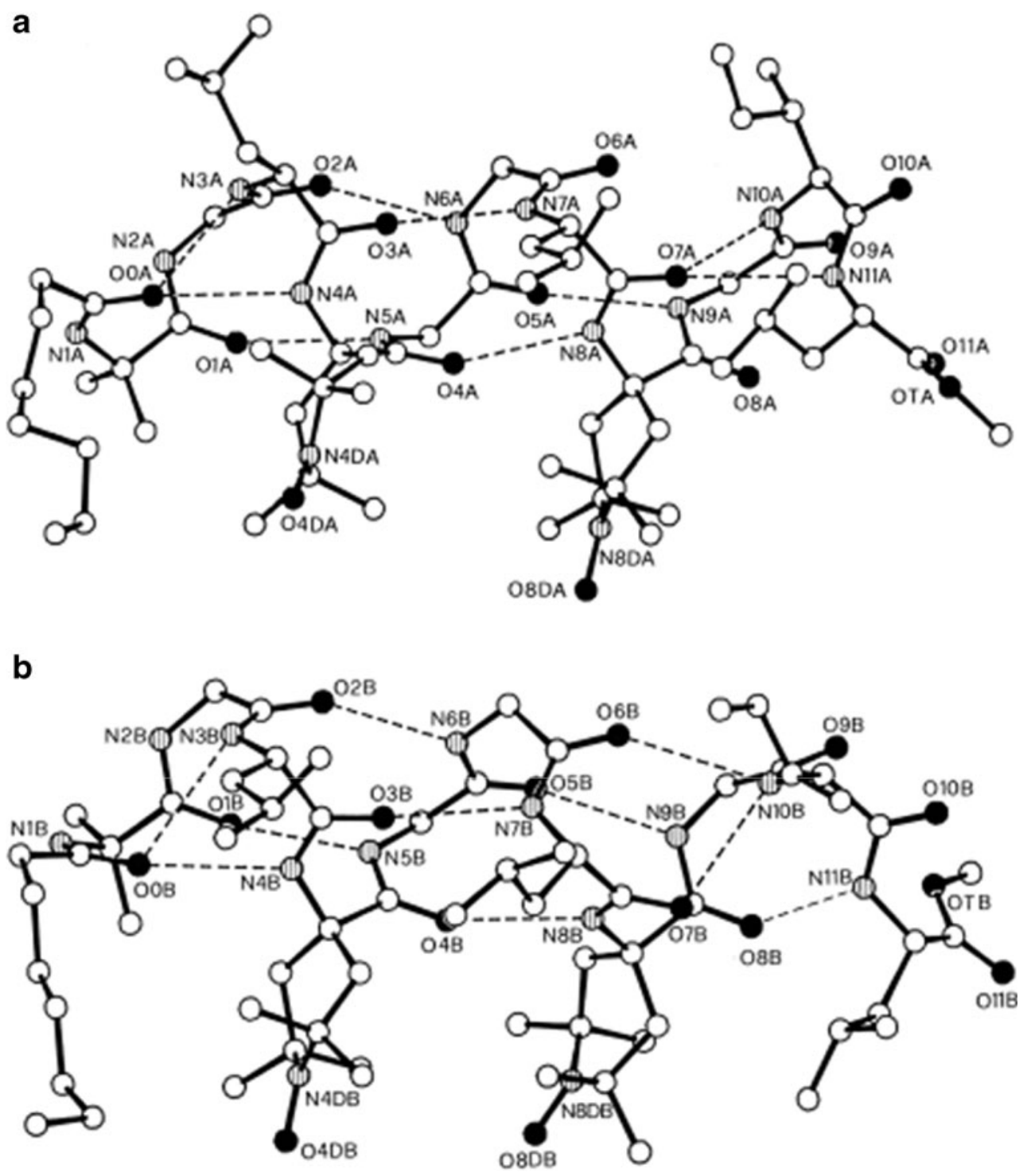

Alamethicin

Alamethicin is a 20-residue linear peptaibol that induces voltage-dependent ion channel activity in lipid membranes. The amino acid sequence of the predominant neutral species, F50/5, is AcUPUAUAQUVUGLUPVUUQQFol (Ac = acetyl, $\mathrm{U}=\mathrm{Aib}, \mathrm{Fol}=$ phenylalaninol). Mono- and double-labeled analogues containing TOAC at positions 1,8 , and 16, and bearing $\mathrm{Glu}(\mathrm{OMe})$ residues instead of Gln at positions 7, 18, and 19, were synthesized by Peggion et al. (2007a). The authors showed that all TOAC-containing derivatives exhibited high activity in a leakage assay. Moreover, patch-clamp experiments showed that $\left[\mathrm{TOAC}^{16}, \mathrm{Glu}(\mathrm{OMe})^{7,18,19}\right.$ ]alamethicin retained the ability to form ion channels in cell membranes, although the current produced was lower compared to the native peptide (Crisma et al. 2007).

X-ray diffraction studies of $\left[\mathrm{TOAC}^{16}, \mathrm{Glu}(\mathrm{OMe})^{7,18,19}\right.$ ]alamethicin showed a similar overall folding to that reported for alamethicin (Fox and Richards 1982). The conformation was largely $\alpha$-helical with a bend at the level of Pro ${ }^{14}$ (Crisma et al. 2007). To assess the solution conformation of TOAC monoand double-labeled analogues, Peggion et al. (2007b) employed CD, FT-IR, and NMR. The results showed that replacement of $\mathrm{Aib}$ residues for TOAC does not affect the peptide $\alpha$-helical conformation significantly. Furthermore, according to PELDOR spectroscopy, the conformation of $\left[\mathrm{TOAC}^{1,16}, \mathrm{Glu}(\mathrm{OMe})^{7,18,19}\right.$ ]alamethicin in egg PC vesicles is $\alpha$-helical at least in the 1-16 segment (Milov et al. 2008). Nitroxide to peptide $\mathrm{NH}$ proton distances were obtained from PRE studies of $\left[\mathrm{TOAC}^{1}, \mathrm{Glu}(\mathrm{OMe})^{7,18,19}\right.$ ]alamethicin, which could be used as long-range distance restraints for NMRbased structure determination (Jose et al. 2011). The authors showed that the peptide solution conformation is in close agreement with that in the crystal state.

Mono-labeled alamethicin analogues (positions 1, 8, and 16) were studied by EPR to characterize their rotational diffusion as 
a function of solvent viscosity and polarity (Marsh et al. 2007a). The spectra showed that the peptides remained monomeric in solvents of relatively high polarity. In weakly polar solvents, Milov et al. (2007) detected aggregation in frozen, glassy solutions at $77 \mathrm{~K}$, as well as in liquid solutions at room temperature. In fluid-phase bilayer membranes of PCs with different chain lengths, alamethicin did not form large stable aggregates (Marsh et al. 2007b, c). This conclusion was based on the lack of spin-spin interactions between monomers in the CW-EPR spectra, together with the fact that the overall rotation of alamethicin is fast in fluid membranes, as shown by ST-EPR experiments that yielded effective correlation times $<30 \mathrm{~ns}$. However, in the low-temperature gel phase of DMPC bilayers, spin-spin interaction did suggest aggregation of the TOAC ${ }^{1}$ derivative (Marsh et al. 2007b). PELDOR spectroscopy showed that the mono-labeled analogues form aggregates with an average number of approximately four in egg PC bilayers at $77 \mathrm{~K}$ (Milov et al. 2009). Furthermore, at a peptide:lipid ratio of 1:100, spin-spin interaction within POPC bilayers was observed by CW-EPR at $77 \mathrm{~K}$, indicating peptide oligomerization (Salnikov et al. 2009). Moreover, spin-spin interactions, monitored by means of ED-EPR at $77 \mathrm{~K}$, indicated a greater tendency to form specific oligomers upon interaction of the peptides with DOPC than with DMPC bilayers (Bartucci et al. 2009).

Based on CW-EPR spectra of aligned samples and from the relative polarity of the environments experienced by the different TOAC positions (1, 8, and 16), Marsh et al. (2007b) concluded that $\left[\mathrm{Glu}(\mathrm{OMe})^{7,18,19}\right]$ alamethicin adopts a transmembrane orientation in DMPC fluid bilayers. The authors used the combined order parameters for the different positions to determine the tilt angle of the peptide long axis relative to the bilayer normal. Effective tilt angles of $17-27^{\circ}$ were found over the temperature range $60-85^{\circ} \mathrm{C}$. The tilt was shown to be relatively small, even at high temperatures, and to increase rather slowly with decreasing chain length (from $13^{\circ}$ to $23^{\circ}$ for $n=18$ and 10 , respectively, at $75^{\circ} \mathrm{C}$ ) (Marsh et al. 2007c). It was concluded that such behavior is insufficient for alamethicin to achieve hydrophobic matching, and that this peptide differs in its mode of incorporation from other helical peptides for which transmembrane orientation has been determined as a function of lipid length. $\mathrm{D}_{2} \mathrm{O}$-ESEEM experiments showed that water exposure of TOAC analogues differs between membranes of saturated (DMPC) and unsaturated (DOPC) lipids (Bartucci et al. 2009). At low temperature, the data indicated a transmembrane location in DOPC, but a more superficial location in DMPC. Corroborating these findings, a transmembrane orientation was found in POPC bilayers, while in DPPC gel phase the peptides switched to an in-plane orientation (Salnikov et al. 2009). In addition, ESEEM experiments showed that, while in the transmembrane orientation positions 8 and 16 are screened from the water phase, in the in-plane orientation only residue 16 is screened from water. It was also shown that in egg PC bilayers at $77 \mathrm{~K}$ the water accessibility follows the order $\mathrm{TOAC}^{1}>$ TOAC $^{8} \sim$ TOAC $^{16}$ (Milov et al. 2009). The use of ED-EPR spectra together with spectral simulations and conventional EPR allowed the detection of rapid librational motions of limited angular amplitude for the three mono-labeled analogues in DMPC bilayers (Bartucci et al. 2008). This study also showed that torsional fluctuations of the peptide backbone take place in the subnanosecond to nanosecond timescale, with little temperature dependence.

\section{Gomesin}

Analogues of the 18-residue HDP gomesin (ZCRRLCYKQ RCVTYCRGR, $Z=$ pyroglutamic acid and disulfide bridges link cysteines 2 and 15, and 6 and 11, Gom) were synthesized with TOAC substituting pyro-Glu both in the native cyclic peptide (TOAC ${ }^{1}$-Gom) and in a linear peptide where the four Cys residues were replaced by Ser (TOAC ${ }^{1}$. $\mathrm{Ser}^{2,6,11,15}$-Gom) (Moraes et al. 2007). EPR spectra showed that, while TOAC ${ }^{1}$-Gom interacted with SDS, above and below the detergent's cmc, the linear peptide only interacted above the cmc. Furthermore, only the cyclic analogue bound to LPC micelles, the interaction being less strong than with SDS. $a_{N}$ values suggested an interfacial location of the peptides. Moreover, the values of rotational correlation times were higher for the cyclic peptide. In addition, CD spectra showed that, although the micelle-bound peptides acquired $\beta$-hairpin conformations, the folds were different for both peptides. Similar to histatin-5 (see below), while the micelle environment induced a $\beta$-hairpin conformation, in TFE the linear peptide acquired $\alpha$-helical conformation.

\section{Histatin-5}

Histatin-5 (DSHAKRHHGYKRKFHEKHHSHRGY, Hst-5) was TOAC-labeled at the $\mathrm{N}$-terminus $\left(\mathrm{TOAC}^{0}{ }^{-} \mathrm{H}\right.$ st-5, Dyszy 2008). As previously found, values of $a_{N}$ and of the $\mathrm{h}_{0} / \mathrm{h}_{-1}$ empirical ratio (where $\mathrm{h}_{0}$ and $\mathrm{h}_{-1}$ are the mid-field and high-field EPR line heights, respectively) reflected the ionization of $\mathrm{TOAC}^{0}$-Hst- $5 \mathrm{~N}$-terminus. The $\mathrm{pK}$ was in the 4.0-5.0 range, corroborating the observation that this value is independent of the nature of the residue next to TOAC. EPR also monitored TFE-induced conformational changes. In spite of its high positive charge, $\mathrm{CD}$ spectra showed that $\mathrm{TOAC}^{0}-\mathrm{Hst}-5$, like its unlabeled counterpart, acquired $\alpha$ helical conformation in the presence of TFE. Interestingly, when the peptide achieved $\alpha$-helical conformation, fluorescence quenching occurred, caused by the closer proximity of the nitroxide to the fluorophores $\left(\mathrm{Tyr}^{10}\right.$ and $\left.\mathrm{Tyr}^{24}\right)$.

Hst-5 interacts with several ions, among them paramagnetic $\mathrm{Cu}^{2+}$ (Melino et al. 2006), the binding site being the $\mathrm{D}^{1} \mathrm{SH}^{3}$ sequence. The $\mathrm{Cu}^{2+}$-promoted loss of intensity in the EPR 
spectra of TOAC ${ }^{0}$-Hst -5 was analyzed by means of the Leigh (1970) theory of spin-spin dipolar coupling making use of parameters taken from Livshits et al. (2001). An NO- $\mathrm{Cu}^{2+}$ distance of $4.8 \AA$ was calculated, in agreement with the proposed binding site.

Both Hst-5 and TOAC ${ }^{0}$-Hst- 5 bound to a greater extent to negatively charged than to zwitterionic micelles. CD spectra indicated that, in contrast with TFE, upon binding, the peptides acquired a $\beta$-turn conformation. EPR spectra of $\mathrm{TOAC}^{0}-\mathrm{Hst}-5$ in the presence of lipid vesicles mimicking the membrane of erythrocytes (negligible surface charge) showed essentially no interaction. In contrast, in the presence of vesicles mimicking the membranes of $E$. coli and C. albicans (negative surface charge), the spectra evinced $\mathrm{pH}$-modulated binding, demonstrating that binding is essentially due to electrostatic interactions. The presence of membrane-bound and free peptide populations allowed calculation of partition coefficients.

\section{Tryptophan-rich tritrpticin and indolicidin}

The interaction of the cationic peptide tritrpticin (VRRFP WWWPFLRR, TRP3) and its N-terminally-labeled analogue (TOAC ${ }^{0}$-TRP3) with micelles and vesicles of variable headgroup composition and surface charge was studied making use of EPR, CD, and fluorescence (Bozelli Jr. 2011). Broadening of the EPR spectral lines demonstrated TOAC ${ }^{0}$-TRP3 interaction with both zwitterionic and negatively charged micelles, binding being more effective in the latter case. In contrast, the interaction with zwitterionic bilayers was negligible. Thus, while electrostatic interactions were important for peptide-bilayer interaction, they played a less important role in the interaction with micelles. $a_{N}$ values demonstrated peptide location at the membrane-water interface. Partition coefficients were calculated, as well as the free energy of binding. The presence of three Trp residues gave rise to electronic transitions in the far-UV, rendering difficult the analysis of CD spectra in terms of peptide secondary structure; nevertheless, binding was seen to promote acquisition of secondary structure, and the peptides conformation was found to depend on aggregate structure: while both peptides acquired similar conformations in all micellar systems, in bilayers, the conformation varied with lipid composition. Binding to membranes promoted an increase in $\operatorname{Trp}$ fluorescence; the decrease in maximal emission wavelength was small, corroborating the notion of peptide location close to the membrane-water interface. Fluorescence quenching by the nitroxide group occurred to a small extent, suggesting that the average distance between this group and the Trp residues is too large to allow for significant quenching effects.

The N-terminally-labeled TOAC derivative $\left(\mathrm{TOAC}^{0}-\right.$ IND) of indolicidin (ILPWKWPWWPWRR-NH $\mathrm{N}_{2}$, IND) was synthesized and fluorescence spectra of both peptides were studied in solution and in the presence of micelles and of phospholipid vesicles (Souto et al., in preparation). In contrast to the negligible quenching effect of TOAC on the fluorescence spectra of TOAC ${ }^{0}$-TRP3 (see above), considerable quenching was observed for $\mathrm{TOAC}^{0}$-IND. Also, in this case, TOAC ${ }^{0}$-IND EPR spectra were $\mathrm{pH}$-sensitive. Moreover, the peptide was able to interact with zwitterionic (LPC) as well as negatively charged (SDS, LPC:LPG) micelles and bilayers (POPC:POPG). However, in contrast to most peptides, TOAC ${ }^{0}$-IND also bound to zwitterionic bilayers (POPC), suggesting that hydrophobic interactions play a more important role in this case. In agreement with this observation, EPR spectra of lipid spin probes showed that addition of native IND increased the order parameter in both micelles and bilayers, although the effect was more pronounced in the former.

\section{Membrane-active peptides: a model peptide, phospholamban, $\beta$-amyloid}

A positively charged model peptide

Taking into account that water-soluble proteins involved in cell signaling carry positively charged domains that promote their attachment to membranes by means of electrostatic interactions, Victor and Cafiso (2001) examined the interaction between PC and PC:PS (with varying PS content) bilayers and basic synthetic peptides containing Lys and a variable number of Phe residues $(n=0,2,3$, and 4$)$, in addition to one internally-placed TOAC residue. EPR spectra were used to gather information about the dynamics of free and membrane-bound peptides, binding free energy, and peptide position on the membrane interface. Binding of all peptides increased upon addition of PS. Furthermore, only Phe-containing peptides bound to PC bilayers. Rotational correlation times indicated that the peptides underwent rapid rotation in solution. Upon binding to negatively charged bilayers, the EPR spectra were broadened. For peptides containing only Lys, correlation times were ca. 4 times longer than those in solution. On the other hand, the incorporation of Phe residues increased the correlation times of membrane-bound peptides ca. 20 times. Powersaturation was employed to estimate the position of the peptides in the membrane. While peptides lacking Phe residues were localized within the double layer, $\sim 5 \AA$ above the level of the lipid phosphate, the incorporation of Phe residues shifted the peptides to a location within the bilayer, several angstroms below the phosphate level. The results support the hypothesis that the position and free energy of membrane binding are determined by long-range coulombic attraction, the hydrophobic effect, and a short-range desolvation force. 
Phospholamban, PLB

PLB is an amphipathic 52 amino acid membrane peptide which regulates the Ca-ATPase (SERCA) in cardiac sarcoplasmic reticulum whose function requires transitions between distinct states of intramolecular dynamics. The group of D.D. Thomas has made a long-time contribution to the understanding of PLB structural and functional properties, mainly through the use of the spin label method. This group undertook the task of synthesizing TOAC-containing PLB derivatives. The synthesis of this peptide including TOAC is a challenge, especially in the addition of TOAC and the next several amino acids. A procedure was described for the synthetic incorporation of TOAC (Karim et al. 2004, 2007; Zhang et al. 2007). EPR spectra were used to optimize the SPPS. EPR of synthetic intermediates, reconstituted into lipid bilayers, was used to ensure complete coupling and Fmoc deprotection. Fmoc-TOAC-OH attachment led to strong probe immobilization, whereas deprotection dramatically mobilized it, producing a peak completely resolved from that observed before deprotection. In the case of TOAC incorporation at position 11, coupling of the next amino acid (Ser) restored strong immobilization, giving a peak completely resolved from that of the preceding step. For several subsequent steps, the effect of coupling and deprotection was similar but less dramatic. Thus, the sensitivity and resolution of EPR provided a quantitative monitor of completion at each of these critical steps in peptide synthesis. Mass spectrometry, $\mathrm{CD}$, and Edman degradation were used in concert with EPR to verify the chemistry and characterize the secondary structure. It was concluded that application of conventional analytical methods in combination with EPR offers an improved approach to optimize the accurate synthesis of TOAC-labeled membrane peptides. Making use of this procedure, PBL derivatives were synthesized, containing a single TOAC residue at positions 0 (TOAC ${ }^{0}$-PLB), 11 $\left(\mathrm{TOAC}^{11}\right.$-PLB), and 24 (TOAC ${ }^{24}$-PLB) in the cytoplasmic domain or at position 46 (TOAC ${ }^{46}$-PLB) in the transmembrane domain. The authors also described a protocol for the functional reconstitution of the spin-labeled protein in lipid vesicles.

EPR spectra were used to probe the structural dynamics of TOAC-containing PLB analogues in lipid bilayers (Karim et al. 2004). The spectra were analyzed by means of simulations making use of the NLSL software (Budil et al. 1996). TOAC $^{46}$-PLB gave rise to a single spectral component indicative of strong immobilization, which was consistent with the presence of a stable, highly ordered transmembrane helix. In contrast, the spectra of the three cytoplasmic domain probes presented twocomponent spectra corresponding to two conformational states, one of which indicated nearly isotropic nanosecond dynamic disorder. For TOAC ${ }^{11}$-PLB, an N-terminal lipid anchor shifted the equilibrium toward the restricted component, whereas $\mathrm{Mg}^{2+}$ had the opposite effect. Relaxation enhancement by $\mathrm{Ni}^{2+}$ ions chelated to lipid headgroups, provided further information about PLB membrane topology, allowing the refinement of an NMR-based structural model. It was concluded that PLB cytoplasmic domain is in dynamic equilibrium between an ordered conformation in direct contact with the membrane surface, and a dynamically disordered form, detached from the membrane and poised to interact with its target.

Based on the knowledge that the PLB transmembrane domain inhibits SERCA at low $\left[\mathrm{Ca}^{2+}\right]$, but the cytoplasmic domain relieves this inhibition upon Ser16 phosphorylation, $\mathrm{TOAC}^{11}$-PLB was reconstituted into membranes in the presence or absence of SERCA (Karim et al. 2006). The analogue showed normal inhibitory function, reversed by $\mathrm{Ser}^{16}$ phosphorylation or micromolar $\left[\mathrm{Ca}^{2+}\right]$. EPR spectra showed that the PLB cytoplasmic domain exhibits two conformations, an ordered (tense) $\mathrm{T}$ state and a dynamically disordered and extended (relaxed) $\mathrm{R}$ state. Phosphorylation shifted the equilibrium toward the $\mathrm{R}$ state, making it more dynamic (hyperextended). It was concluded that the relief of SERCA inhibition by PLB phosphorylation is due to an order-to-disorder transition in PLB cytoplasmic domain, which allows this domain to extend above the membrane surface and induce a structural change in the cytoplasmic domain of SERCA.

Multifrequency EPR is a powerful approach for analysis of complex rotational dynamics of proteins. Since the function of PLB requires transitions between distinct states of intramolecular dynamics, multifrequency experiments were used to define the peptide's multistate structural dynamics in a lipid bilayer (Nesmelov et al. 2007). EPR spectra of $\mathrm{TOAC}^{11}$-PLB and TOAC ${ }^{46}$-PLB at $9.4 \mathrm{GHz}$ (X-band) and $94 \mathrm{GHz}$ (W-band) were analyzed in terms of anisotropic rotational diffusion of the two domains. Motion of the transmembrane domain was highly restricted, while the cytoplasmic domain exhibited two distinct conformations, a major one with moderately restricted nanosecond dynamics (T) and another with nearly unrestricted subnanosecond motion (R). The global analysis of spectra at two frequencies yielded much more precise values for rotational correlation times and order parameters than those determined at either frequency alone.

\section{$\beta$-amyloid peptide}

Based on evidence that the lipid matrix of neuronal membranes plays a role in $\beta$-amyloid peptide $\beta$-sheet oligomerization, Esposito et al. (2006) investigated the interaction between a $\beta$-amyloid peptide fragment (GSNKGAAIIGLM, $\mathrm{A} \beta_{25-35}$ ) containing TOAC at the $\mathrm{N}$ - or $\mathrm{C}$-terminus with SDS and DPC micelles, and bilayer vesicles of variable lipid 
composition employing EPR and CD. A comparison of the $\mathrm{CD}$ spectra of the native with those of the labeled peptides revealed that TOAC did not affect peptide conformation. While the CD spectra showed an unordered structure in aqueous solution, the peptides acquired helical conformation upon binding to micelles. Moreover, the peptides also became more structured upon interacting with negatively charged bilayers. When the membranes contained cholesterol and sphingomyelin, present in lipid rafts, a transition from $\alpha$ helical to $\beta$-sheet conformation was observed. EPR spectra showed that, upon binding to micelles, while the peptide containing $\mathrm{C}$-terminally-bound TOAC gave rise to a more strongly immobilized population, the $\mathrm{N}$-terminally-labeled counterpart yielded spectra typical of a more mobile population. A model was proposed whereby the peptide $\mathrm{C}$-terminal portion is highly membrane-associated, while the $\mathrm{N}$-terminal part extends into the aqueous phase, with occasional contacts with the lipid headgroup region.

\section{Peptide-macromolecule interaction}

In recent years novel applications of TOAC have appeared, among those, the use of TOAC-labeled peptides to monitor peptide-peptide, peptide-protein, and peptide-RNA interactions. As already mentioned (see "Angiotensin and bradykinin"), Lopes and collaborators (2008) described an EPR approach to explore the details of angiotensin II binding site to its $\mathrm{AT}_{1}$ receptor. While the active $\mathrm{TOAC}^{1}$-AII analogue was found to interact with a peptide composed of portions of the receptor N-terminal domain and third extracellular loop, inactive TOAC ${ }^{4}$-AII did not display this ability.

Zhang et al. (2008) synthesized by SPPS the basic 55residue protein $\mathrm{NCp}-7$ of the HIV-1 nucleocapsid, as well as an analogue with TOAC before the $\mathrm{N}$-terminal residue (TOAC ${ }^{0}$-NCp-7). NCp-7 contains two weakly interacting $\mathrm{Zn}$-finger domains and has numerous critical functions in HIV-1 replication. TOAC ${ }^{0} \mathrm{NCp}-7$ displayed biological activity similar to that of the native protein. EPR spectra were analyzed by means of computer simulations making use of the NLSL method (Budil et al. 1996). The spectra indicated fast motion of N-terminally located TOAC, both in the holo $\left(\mathrm{Zn}^{2+}\right.$ containing) and in the apo (non- $\mathrm{Zn}^{2+}$ ) protein; the rate of motion decreased upon interaction with a stem-loop RNA. The conformation of both holo- and apo-TOAC ${ }^{0}-\mathrm{NCp}-7$ as a function of TFE was investigated using $E P R$ and $C D$ spectroscopies. Upon addition of TFE, CD spectra indicated that apo-TOAC ${ }^{0}-\mathrm{NCp}-7$ shifted from a disordered to $\alpha$-helical conformation. Accordingly, EPR spectra revealed a great increase in rotational correlation times, due both to protein conformational changes and to TFEpromoted increase of microviscosity. The binding of $\mathrm{Zn}^{2+}$ in holo-TOAC ${ }^{0}$-NCp-7 caused a loss of helical content in TFE, in agreement with the considerable line narrowing in the EPR spectra.

The C-terminal tail of transducin $\alpha$-subunit, Gt $\alpha(340$ 350) (IKENLKDCGLF), binds to and stabilizes rhodopsin's active conformation upon photoactivation $\left(\mathrm{R}^{*}\right)$ (Hamm et al. 1988; Dratz et al. 1993). NMR results showed that, upon binding, Gt $\alpha(340-350)$ acquires an ordered continuous helical conformation terminated by a C-terminal capping motif (Kisselev et al. 1998). Five spin-labeled analogues of Gt $\alpha(340-350)$ were synthesized and were able to bind and stabilize $\mathrm{R}^{*}$ in a manner similar to that of the native peptide (Van Eps et al. 2010). In this study, TOAC replaced residue 343 in both the native sequence and in a 100-fold higheraffinity peptide (VLEDLKSCGLF) reported from phage display (Martin et al. 1996). In addition, 3-carboxy-PROXYL was incorporated at the N-terminus in both peptides. A fifth analogue was synthesized containing the high affinity sequence and both PROXYL at the N-terminus and TOAC replacing $\mathrm{Gly}^{348}$. Upon binding to $\mathrm{R}^{*}$, all four mono-labeled peptides gave rise to two-component EPR spectra, due to a protein-bound population and another free in solution. Spectral subtractions showed that the protein-bound populations were strongly immobilized, the TOAC-containing peptides yielding higher correlation times than those carrying the PROXYL moiety. DEER experiments showed that the distances between nitroxides in doublylabeled PROXYL/TOAC ${ }^{348}$-Gt $\alpha(340-350)$ varied in the range 18-34 $\AA$ in solution, a result consistent with an ensemble of conformations for the unbound peptide. In contrast, a narrow distance distribution centered at $19 \AA$ was found for $\mathrm{R}^{*}$-bound Gt $\alpha(340-350)$, consistent with the configuration determined by crystal studies (Scheerer et al. 2008) and by NMR (Kisselev et al. 1998). It was concluded that TOAC and PROXYL spin labels can be valuable tools to explore the structure and conformational changes at the rhodopsin-G-protein interface.

The ATP-binding cassette transporter associated with antigen processing (TAP) acts in the adaptive immune defense against infected or malignantly transformed cells. The protein translocates proteasomal degradation products into the lumen of the endoplasmic reticulum for loading onto MHC class I molecules, displaying a broad substrate spectrum, which suggests that the substratebinding pocket presents high structural flexibility. Making use of EPR spectroscopy, Herget et al. (2011) examined conformational properties of the high affinity HLA-B27 restricted epitope RRYQSTEL. Information about side chain dynamics and environmental polarity was obtained from analysis of spectra of 3-iodoacetamido-PROXYL covalently attached to peptides where each one of the nine residues were mutated to Cys, while TOAC-labeled peptides, with TOAC replacing each of the nine residues, were used to monitor backbone properties. Differences in affinity, dynamics, and polarity 
were found to depend on the spin probe position: while the side chains mobility was strongly restricted at the ends of the peptide, the central region was flexible, suggesting a central bulge. DEER experiments on doubly-labeled peptides where one PROXYL label was placed at position 8 and the second at position 2,4 , or 6 , allowed the determination of interspin distances in order to derive the conformations of TAP-bound peptides. Spectral simulations based on a rotamer library led to the conclusion that peptides bind to TAP in an extended kinked structure, similar to that found for peptides bound to MHC class I proteins.

Several approaches were employed to address the role of apoprotein $\mathrm{E}$ (apoE) isoforms in the mechanism of development of Alzheimer's disease, since the interaction between apoE3 and the amyloid $\beta$ peptide $(A \beta)$ is proposed to be involved in the process of $A \beta$ misfolding and aggregation (Petrlova et al. 2011). Among these approaches, an analogue where TOAC replaced $\mathrm{Ser}^{26}$ in the 40 -residue peptide $\left(\mathrm{TOAC}^{26}-\mathrm{A} \beta\right)$ was synthesized that displayed oligomerization and toxic properties similar to those of the native peptide. EPR spectra of the labeled peptide were obtained for the monomeric and oligomeric forms, the latter reporting a higher degree of probe immobilization. The spectra were simulated making use of the NLSL software (Budil et al. 1996) and showed an increase in rotational correlation time of ca. 6 times upon oligomerization. In order to avoid spinspin interactions, oligomers were prepared where the labeled peptide was diluted by the addition of native $A \beta$ at a 1:3 proportion. EPR spectra of monomeric TOAC ${ }^{26}$ $A \beta$ showed a higher affinity for apoE3 than for apoE4. The apoE-A $\beta$ interaction was also examined by analysis of EPR spectra of different apoE site-directed spin-labeled isoforms, as well as by means of surface plasmon resonance, yielding similar conclusions.

An even more recent very promising approach is the use of TOAC-labeled peptides in paramagnetic relaxation enhancement (PRE) experiments to obtain information about the distances between TOAC and amino acids in a protein to which the labeled peptide is bound, allowing the determination of the structure of the complex. The advantage of using TOAC lies in the fact that its rigid structure restricts the region of interaction, decreasing averaging effects and yielding better-defined distances (Lindfors et al. 2008; Su and Otting 2010; Keizers and Ubbink 2011). This approach was used for the first time by Lindfors et al. (2008) to examine the interaction between TOAC-labeled nonapeptides derived from focal adhesion kinase (FAK) and the Src homology 3 (SH3) domain of Src kinase. When TOAC replaced a residue located in the peptide binding motif, this caused a substantial decrease of the binding affinity. In contrast, when TOAC was placed just outside the binding motif, the binding constant was essentially unaffected. It was found that, although the SH3 domain binds weakly and transiently to Pro-rich peptides from FAK, the interaction is not very dynamic and the relative position of the spin label to the protein is well defined.

Antibodies have a wide range of biological and biotechnical applications. Selective interaction with an epitope is known to be crucial and to depend on paratope conformation. Mangels et al. (2010) applied PRE NMR spectroscopy to determine the orientation of helix 1 of the prion protein, which is the epitope for the therapeutically active anti-prion $\operatorname{scF}(\mathrm{v})$ fragment W226. For this purpose, the peptide fragment W226 was labeled with TOAC and PRE experiments were performed to elucidate the structure of the paratopeepitope interface.

\section{Use of TOAC EPR spectra to monitor and improve solid phase peptide synthesis}

The first studies of the applications of EPR to TOAClabeled peptidyl-resins were reported about two decades ago (Nakaie et al. 1988, 1990) and were extended to focus the dynamics of the polymer matrix through the determination of the mobility of peptide chains in the resin bead as a function of solvent. Cilli et al. (1997) introduced an EPR approach to monitor peptide chain aggregation inside resin beads. In this work, for the first time in peptide synthesis, EPR spectroscopy allowed the detection of different degrees of chain aggregation as a function of solvent and resin loading. Differently from NMR or FT-IR spectra, which reflected the solvation of the whole peptide chain in the bead, the EPR method allowed estimation of the chain aggregation/accessibility in the $\mathrm{N}$-terminal region, where the extent of steric hindrance is critical for the success of the synthetic process. Later, Cilli et al. (1999) studied the strongly aggregating VVLGAAIV and ING sequences in benzhydrylamine resin with different amino group contents to evaluate the extent of chain association within the beads. The model peptidyl-resins were first labeled with FmocTOAC at their N-terminus and their solvation properties in different solvents were evaluated. This work, as well as the studies of Marchetto et al. (2005) and Nakaie et al. (2006), demonstrated the possibility of correlating EPR spectral parameters with different factors that govern polymersupported reactions during synthesis. The effect of temperature (Ribeiro et al. 2001) and of amino acid side chains protecting groups (Cilli et al. 2007) on chain dynamics inside resin beads were also monitored by EPR.

Another study focused on a very hydrophobic 34-residue peptide (TM-34, CTVAEIYLGNLAGADLILASGLPF WAITIANNFD) which corresponds to a transmembrane segment (residues 69-97) of the rat B2 BK receptor. Due to the difficulty in synthesizing and purifying TM-34, Oliveira et al. (2002) investigated the association properties of shorter peptides from this sequence. The work focused on 
peptide-resin solvation/swelling (measurement of bead size), chain mobility (assessed by means of EPR spectra of TOAClabeled peptidyl-resin), and the kinetics of the coupling reaction.

The use of TOAC EPR spectra to investigate how physicochemical conditions influence the efficacy of peptide synthesis within polymer beads proved to be a powerful tool for the achievement of a fundamental goal in this field, namely, the improvement of the yield of synthesis.

\section{Concluding remarks}

The introduction of TOAC represented a new approach for EPR studies of peptides where this unnatural paramagnetic amino acid can be linked to the peptide backbone via a peptide bond. In view of TOAC's rigid cyclic structure, studies of backbone dynamics are not influenced by rotations of bonds in side chain residues, or those between side chains and the nitroxide group in side chain-attached spin labels. Studies making use of TOAC have yielded a wealth of information about the structural and dynamical aspects of synthetic and biologically active peptides. The combined use of a variety of physical techniques in studies of TOAC-containing peptides has contributed to the understanding of the conformational properties of these molecules, and, therefore, their function. The use of TOAC has shed light on the role of important physicochemical parameters for the improvement of peptide synthesis. New approaches have appeared, such as paramagnetic enhanced relaxation NMR, where the rigid attachment of TOAC to the peptide backbone allows more precise determination of distances for the mapping of peptide-protein complexes. It is foreseeable that other novel approaches will expand the fields of TOAC applications in the future.

Acknowledgements We acknowledge the financial support of the agencies FAPESP, CAPES, CNPq. J.C.B.Jr is a FAPESP PhD fellowship, N.M. and R.F.F.V. are FAPESP post-doctoral fellows, S.S. and C.R.N. are $\mathrm{CNPq}$ research fellows.

\section{Conflict of interest None.}

Open Access This article is distributed under the terms of the Creative Commons Attribution Noncommercial License which permits any noncommercial use, distribution, and reproduction in any medium, provided the original author(s) and source are credited.

\section{References}

Altenbach C, Flitsch SL, Khorana HG, Hubbell WL (1989) Structural studies on transmembrane proteins. 2. Spin labeling of bacteriorhodopsin mutants at unique cysteines. Biochemistry 28:7806-7812
Anderson DJ, Hanson P, McNulty J, Millhauser G, Monaco V, Formaggio F, Crisma M, Toniolo C (1999) Solution structures of TOAC-labeled trichogin GA IV peptides from allowed $(\mathrm{g} \approx 2)$ and half-field electron spin resonance. J Am Chem Soc 121:6919-6927

Atherton E, Sheppard RC (1989) Solid phase peptide synthesis: a practical approach. I.L.R. Press, Oxford

Balog M, Kálai T, Jeko J, Berente Z, Steinhoff H-J, Engelhard M, Hideg K (2003) Synthesis of new conformationally rigid paramagnetic $\alpha$-amino acids. Tetrahedron Lett 44:9213-9217

Barbosa SR, Cilli EM, Lamy-Freund MT, Castrucci AM, Nakaie CR (1999) First synthesis of a fully active spin-labeled peptide hormone. FEBS Lett 446:45-48

Bartucci R, Guzzi R, De Zotti M, Toniolo C, Sportelli L, Marsh D (2008) Backbone dynamics of alamethicin bound to lipid membranes: spin-echo electron paramagnetic resonance of TOAC-spin labels. Biophys J 94:2698-2705

Bartucci R, Guzzi R, Sportelli L, Marsh D (2009) Intramembrane water associated with TOAC spin-labeled alamethicin: electron spinecho envelope modulation by $\mathrm{D}_{2} \mathrm{O}$. Biophys J 96:997-1007

Bettio A, Gutewort V, Pöppl A, Dinger MC, Zschörnig O, Klaus A, Toniolo C, Beck-Sickinger AG (2002) Electron paramagnetic resonance backbone dynamics studies on spin-labelled neuropeptide Y analogues. J Pept Sci 8:671-682

Bozelli Jr. JC (2011) MSc dissertation, University of São Paulo

Brière R, Lemaire H, Rassat A (1965) Nitroxydes XV: Synthèse et étude de radicaux libres stables piperidiniques et pyrrolidinique. Bull Soc Chim Fr 3273-3283

Brogden KA (2005) Antimicrobial peptides: pore formers or metabolic inhibitors in bacteria? Nat Rev Microbiol 3:238-250

Budil DE, Lee S, Saxena S, Freed JH (1996) Nonlinear-least-squares analysis of slow-motion EPR spectra in one and two dimensions using a modified Levenberg-Marquardt algorithm. J Magn Res Ser A 120:155-189

Bui TTT, Formaggio F, Crisma M, Monaco V, Toniolo C, Hussain R, Siligardi G (2000) TOAC: a useful $\mathrm{C}^{\alpha}$-tetrasubstituted $\alpha$-amino acid for peptide conformational analysis by $\mathrm{CD}$ spectroscopy in the visible region. Part I. J Chem Soc, Perkin Trans 2:1043-1046

Cann JR, London RE, Unkefer CJ, Vavrek RJ, Stewart JM (1987) CD-n. m.r. study of the solution conformation of bradykinin analogs containing $\alpha$-aminoisobutyric acid. Int J Pept Protein Res 29:486-496

Carlotto S, Cimino P, Zerbetto M, Franco L, Corvaja C, Crisma M, Formaggio F, Toniolo C, Polimeno A, Barone V (2007) Unraveling solvent-driven equilibria between $\alpha$ - and $3_{10}$-helices through an integrated spin labeling and computational approach. J Am Chem Soc 129:11248-11258

Cilli EM, Oliveira E, Marchetto R, Nakaie CR (1996) Correlation between solvation of peptide-resins and solvent properties. J Org Chem 61:8992-9000

Cilli EM, Marchetto R, Schreier S, Nakaie CR (1997) Use of spin label EPR spectra to monitor peptide chain aggregation inside resin beads. Tetrahedron Lett 38:517-520

Cilli EM, Marchetto R, Schreier S, Nakaie CR (1999) Correlation between the mobility of spin-labeled peptide chains and resin solvation: an approach to optimize the synthesis of aggregating sequences. J Org Chem 64:9118-9123

Cilli EM, Vicente EF, Crusca E, Nakaie CR (2007) EPR investigation of the influence of side chain protecting groups on peptideresin solvation of the Asx and Glx model containing peptides. Tetrahedron Lett 48:5521-5524

Cornish VW, Benson DR, Altenbach CA, Hideg K, Hubbell WL, Schultz PG (1994) Site-specific incorporation of biophysical probes into proteins. Proc Natl Acad Sci USA 91:2910-2914

Corvaja C, Sartori E, Toffoletti A, Formaggio F, Crisma M, Toniolo C (2000a) Interaction between TOAC free radical and photoexcited triplet chromophores linked to peptide templates. Biopolymers $55: 486-495$ 
Corvaja C, Sartori E, Toffoletti A, Formaggio F, Crisma M, Toniolo C, Mazaleyrat JP, Wakselman M (2000b) CIDEP effects of intramolecular quenching of singlet and triplet excited states by nitroxide radicals in oligopeptides: a potentially useful new method for investigating peptide secondary structures in solution. Chem-Eur J 6:2775-2782

Crisma M, Monaco V, Formaggio F, Toniolo C, George C, FlippenAnderson JL (1997) Crystallographic structure of a helical lipopeptaibol antibiotic analogue. Lett Pept Sci 4:213-218

Crisma M, Formaggio F, Mezzato S, Toniolo C, Savrda J, Mazaleyrat JP, Wakselman M (2000) Afc can adopt either the fully extended or a turn conformation. Lett Pept Sci 7:123-131

Crisma M, Deschamps JR, George C, Flippen-Anderson JL, Kaptein B, Broxterman QB, Moretto A, Oancea S, Jost M, Formaggio F, Toniolo C (2005) A topographically and conformationally constrained, spin-labeled, alpha-amino acid: crystallographic characterization in peptides. J Pept Res 65:564-579

Crisma M, Monaco V, Formaggio F, Toniolo C, George C, FlippenAnderson JL (2007) Crystallographic structure of a helical lipopeptaibol antibiotic analogue. Lett Pept Sci 4:213-218

Csekö J, Hankovszki HO, Hideg K (1985) Synthesis of novel, highly reactive 1-oxyl-2,2,6,6-tetramethyl-1,2,5,6-tetrahydropyridine derivatives. Can J Chem 63:940-943

D'Amore M, Improta R, Barone V (2003) Conformational behavior and magnetic properties of a nitroxide amino acid derivative in vacuo and in aqueous solution. J Phys Chem A 107:6264-6269

Devaux P, McConnell HM (1972) Lateral diffusion in spin-labeled phosphatidylcholine multilayers. J Am Chem Soc 94:4475-4481

Dratz EA, Furstenau JE, Lambert CG, Thireault DL, Rarick H, Schepers T, Pakhlevaniants S, Hamm HE (1993) NMR structure of a receptor-bound G-protein peptide. Nature 363:276-281

Duarte DL, Malavolta L, Vieira RFF, Oliveira L, Schreier S, Nakaie CR (2011) An unusual spectroscopic approach for assessing the binding site of the bradykinin B2 receptor. In: Bridges B, Lebl M (eds) Peptides. Prompt Scientific Publishing, San Diego, pp 254-255

Dupeyre RM, Lemaire H, Rassat A (1964) Nitroxydes (VII): radicaux libres stables pyrrolidiniques. Tetrahedron Lett 27:1781-1785

Dutot L, Wright K, Gaucher A, Wakselman M, Mazaleyrat J-P, De Zotti M, Peggion C, Formaggio F, Toniolo C (2008) The Bip method, based on the induced circular dichroism of a flexible biphenyl probe in terminally protected -Bip-Xaa*- dipeptides, for assignment of the absolute configuration of $\beta$-amino acids. J Am Chem Soc 130:5986-5992

Dyszy FH (2008) PhD thesis, University of São Paulo

Elsässer C, Monien B, Haehnel W, Bittl R (2005) Orientation of spin labels in de novo peptides. Magn Reson Chem 43:S26-S33

Epand R, Epand RM, Monaco V, Stoia S, Formaggio F, Crisma M, Toniolo C (1999) The antimicrobial peptide trichogin and its interaction with phospholipid membranes. Eur J Biochem 266:1021-1028

Esposito C, Tedeschi A, Scrima M, D'errico G, Ottaviani MF, Rovero P, D'ursi AM (2006) Exploring interaction of $\beta$-amyloid segment (25-35) with membrane models through paramagnetic probes. J Pept Sci 12:766-774

Fernandez RM, Vieira RF, Nakaie CR, Lamy MT, Ito AS (2005a) Acid-base titration of melanocortin peptides: evidence of Trp rotational conformers interconversion. Biopolymers 80:643-650

Fernandez RM, Vieira RF, Nakaie CR, Ito AS, Lamy MT (2005b) Peptide-lipid interaction monitored by spin-labeled biologically active melanocortin peptides. Peptides 26:1825-1834

Fields GB, Noble RL (1990) Solid phase peptide synthesis utilizing 9fluorenylmethoxycarbonyl amino acids. Int J Pept Protein Res $35: 161-214$

Flippen-Anderson JL, George C, Valle G, Valente E, Bianco A, Formaggio F, Crisma M, Toniolo C (1996) Crystallographic characterization of geometry and conformation of TOAC, a nitroxide spin-labelled $C^{\alpha, \alpha}$-disubstituted glycine, in simple derivatives and model peptides. Int J Pept Protein Res 47:231-238
Formaggio F, Bonchio M, Crisma M, Peggion C, Mezzato S, Polese A, Barazza A, Antonello S, Maran F, Broxterman QB, Kaptein B, Kamphuis J, Vitale RM, Saviano M, Benedetti E, Toniolo C (2002) Nitroxyl peptides as catalysts of enantioselective oxidations. Chem-Eur J 8:84-93

Fox RO Jr, Richards FM (1982) A voltage-gated ion channel model inferred from the crystal structure of alamethicin at $1.5-\AA$ resolution. Nature 300:325-330

Gatto E, Stella L, Formaggio F, Toniolo C, Lorenzelli L, Venanzi M (2008) Electroconductive and photocurrent generation properties of self-assembled monolayers formed by functionalized, conformationally-constrained peptides on gold electrodes. J Pept Sci 14:184-191

Hamm HE, Deretic D, Arendt A, Hargrave PA, Koenig B, Hofmann KP (1988) Site of G protein binding to rhodopsin mapped with synthetic peptides from the $\alpha$ subunit. Science 241:832-835

Hanson P, Millhauser G, Formaggio F, Crisma M, Toniolo C (1996a) ESR characterization of hexameric, helical peptides using double TOAC spin labeling. J Am Chem Soc 118:7618-7625

Hanson P, Martinez G, Millhauser G, Formaggio F, Crisma M, Toniolo C, Vita C (1996b) Distinguishing helix conformations in alaninerich peptides using the unnatural amino acid TOAC and Electron Spin Resonance. J Am Chem Soc 118:271-272

Hanson P, Anderson DJ, Martinez G, Millhauser G, Formaggio F, Crisma M, Toniolo T, Vita C (1998) Electron spin resonance and structural analysis of water soluble, alanine-rich peptides incorporating TOAC. Mol Phys 95:957-966

Herget M, Baldauf C, Schölz C, Parcej D, Wiesmüller KH, Tampé R, Abele R, Bordignon E (2011) Conformation of peptides bound to the transporter associated with antigen processing (TAP). Proc Natl Acad Sci USA 108:1349-1354

Hoffmann AK, Henderson AT (1961) A new stable free radical: di-tbutylnitroxide. J Am Chem Soc 83:4671-4672

Hsia J-C, Schneider H, Smith ICP (1970) Spin label studies of oriented phospholipids: egg lecithin. Biochim Biophys Acta 202:399-402

Hubbell WL, McConnell HM (1968) Spin-label studies of the excitable membranes of nerve and muscle. Proc Natl Acad Sci USA 61:12-16

Hubbell WL, McConnell HM (1969) Motion of steroid spin labels in membranes. Proc Natl Acad Sci USA 63:16-22

Hubbell WL, McConnell HM (1971) Molecular motion in spin-labeled phospholipids and membranes. J Am Chem Soc 93:314-326

Inbaraj JJ, Cardon TB, Laryukhin M, Grosser SM, Lorigan GA (2006) Determining the topology of integral membrane peptides using EPR spectroscopy. J Am Chem Soc 128:9549-9554

Inbaraj JJ, Laryukhin M, Lorigan GA (2007) Determining the helical tilt angle of a transmembrane helix in mechanically aligned lipid bilayers using EPR spectroscopy. J Am Chem Soc 129: $7710-7711$

Jose RA, De Zotti M, Peggion C, Formaggio F, Toniolo C, De Borggraeve WM (2011) Comparison of distance information in $\left[\mathrm{TOAC}^{1}, \mathrm{Glu}(\mathrm{OMe})^{7,18,19}\right]$ alamethicin $\mathrm{F} 50 / 5$ from paramagnetic relaxation enhancement measurements with data obtained from an X-ray diffraction-based model. J Pept Sci 17:377-382

Karim CB, Kirby TL, Zhang Z, Nesmelov Y, Thomas DD (2004) Phospholamban structural dynamics in lipid bilayers probed by a spin label rigidly coupled to the peptide backbone. Proc Natl Acad Sci USA 101:14437-14442

Karim CB, Zhang Z, Howard EC, Torgersen KD, Thomas DD (2006) Phosphorylation-dependent conformational switch in spin-labeled phospholamban bound to SERCA. J Mol Biol 358:1032-1040

Karim CB, Zhang Z, Thomas DD (2007) Synthesis of TOAC spin-labeled proteins and reconstitution in lipid membranes. Nat Protoc 2:42-49 
Karp ES, Inbaraj JJ, Laryukhin M, Lorigan GA (2006) Electron paramagnetic resonance studies of an integral membrane peptide inserted into aligned phospholipid bilayer nanotube arrays. J Am Chem Soc 128:12070-12071

Keizers PHJ, Ubbink M (2011) Paramagnetic tagging for protein structure and dynamics analysis. Prog Nucl Magn Reson Spectrose 58:88-96

Kisselev OG, Kao J, Ponder JW, Fann YC, Gautam N, Marshall GR (1998) Light-activated rhodopsin induces structural binding motif in G protein $\alpha$-subunit. Proc Natl Acad Sci USA 95:4270-4275

Kornberg RD, McConnell HM (1971) Inside-outside transitions of phospholipids in vesicle membranes. Biochemistry 10:11111120

Lebedev OL, Kazarnovskii SN (1959) Papers on Chemistry and Chemical Technology, Gor'kii, 649 (in Russian)

Leigh JS Jr (1970) ESR rigid-lattice line shape in a system of two interacting spins. J Chem Phys 52:2608-2612

Lex L, Hideg K, Hankovszky HO (1982) Nitroxides. IX. Synthesis of nitroxide free radical $\alpha$-amino acids. Can J Chem 60:1448-1451

Lindfors HE, de Koning PE, Drijfhout JW, Venezia B, Ubbink M (2008) Mobility of TOAC spin-labelled peptides binding to the Src SH3 domain studied by paramagnetic NMR. J Biomol NMR 41:157-167

Livshits VA, Dzikovski BG, Marsh D (2001) Mechanism of relaxation enhancement of spin labels in membranes by paramagnetic ion salts: dependence on $3 \mathrm{~d}$ and $4 \mathrm{f}$ ions and on the anions. J Magn Res 148:221-237

Lopes DD, Poletti EF, Vieira RFF, Jubilut GN, Oliveira L, Paiva ACM, Schreier S, Nakaie CR (2008) A proposed EPR approach to evaluating agonist binding site of a peptide receptor. Int J Pept Res Ther 14:121-126

Luckhurst GR (1976) Biradicals as spin probes. In: Berliner LJ (ed) Spin labeling theory and applications. Academic New York, pp 133-181

Malavolta L, Oliveira E, Cilli EM, Nakaie CR (2002) Solvation of polymers as models for solvent effect investigation: proposition of a novel polarity scale. Tetrahedron 58:4383-4394

Malavolta L, Poletti EF, Silva EH, Schreier S, Nakaie CR (2008) Application of electron paramagnetic resonance spectroscopy for validation of the novel (AN plus DN) solvent polarity scale. Int $\mathrm{J}$ Mol Sci 9:1321-1332

Mangels C, Kellner R, Einsiedel J, Weiglmeier PR, Rosch P, Gmeiner P, Schwarzinger S (2010) The therapeutically anti-prion active antibody-fragment scFv-W226: paramagnetic relaxationenhanced NMR spectroscopy aided structure elucidation of the paratope-epitope interface. J Biomol Struct Dyn 28:13-22

Marchetto R, Schreier S, Nakaie CR (1993) A novel spin-labeled amino acid derivative for use in peptide synthesis: (9-fluorenylmethyloxycarbonyl)-2,2,6,6-tetramethyl piperidine-N-oxyl-4amino-4-carboxylic acid. J Am Chem Soc 115:11042-11043

Marchetto R, Cilli EM, Jubilut GN, Schreier S, Nakaie CR (2005) Determination of site-site distance and site concentration within polymer beads: a combined swelling-electron paramagnetic resonance study. J Org Chem 70:4561-4568

Marín N (2007) PhD thesis, University of São Paulo

Marín N, Vieira RFF, Nakaie CR, Schreier S (2011) Spectroscopic studies of conformational properties of bradykinin and its TOAClabeled derivatives in solution and in the presence of model membranes. In: Lebl M (ed) Peptides. Building Bridges. Prompt Publishing, San Diego, pp 242-243

Marsh D (2006) Orientation of TOAC amino-acid spin labels in $\alpha$ helices and $\beta$-strands. J Magn Reson 180:305-310

Marsh D, Toniolo C (2008) Polarity dependence of EPR parameters for TOAC and MTSSL spin labels: correlation with DOXYL spin labels for membrane studies. J Magn Reson 190:211-221
Marsh D, Jost M, Peggion C, Toniolo C (2007a) Solvent dependence of the rotational diffusion of TOAC-spin-labeled alamethicin. Chem Biodivers 4:1269-1274

Marsh D, Jost M, Peggion C, Toniolo C (2007b) TOAC spin labels in the backbone of alamethicin: EPR studies in lipid membranes. Biophys J 92:473-481

Marsh D, Jost M, Peggion C, Toniolo C (2007c) Lipid chain-length dependence for incorporation of alamethicin in membranes: electron paramagnetic resonance studies on TOAC-spinlabeled analogs. Biophys J 92:4002-4011

Martin EL, Rens-Domiano S, Schatz PJ, Hamm HE (1996) Potent peptide analogues of a $\mathrm{G}$ protein-receptor-binding region obtained with a combinatorial library. J Biol Chem 271: 361-366

McNulty JM, Millhauser GL (2002) TOAC the rigid nitroxide side chain. In: Berliner LJ, Eaton GR, Eaton SS (eds) Biological magnetic resonance, vol 19. Kluwer, New York, pp 277-307

McNulty JC, Silapie JL, Carnevali M, Farrar CT, Griffin RG, Formaggio F, Crisma M, Toniolo C, Millhauser GL (2000) Electron spin resonance of TOAC labeled peptides: folding transitions and high frequency spectroscopy. Biopolymers 55:479-485

Melino S, Gallo M, Trotta E, Mondello F, Paci M, Petruzzelli R (2006) Metal-binding and nuclease activity of an antimicrobial peptide analogue of the salivary histatin 5. Biochemistry 45:15373-15383

Merrifield RB (1963) Solid phase peptide synthesis. I. The synthesis of a tetrapeptide. J Am Chem Soc 85:2149-2154

Miick SM, Martinez GV, Fiori WR, Todd AP, Millhauser GL (1992) Short alanine-based peptides may form 310 -helices and not $\alpha$ helices in aqueous solution. Nature 359:653-655

Milov AD, Tsvetkov YD, Raap J (2000a) Aggregation of trichogin analogs in weakly polar solvents: PELDOR and ESR studies. Appl Magn Reson 19:215-226

Milov AD, Tsvetkov YD, Formaggio F, Crisma M, Toniolo C, Raap J (2000b) Self-assembling properties of membrane-modifying peptides studied by PELDOR and CW-ESR spectroscopies. J Am Chem Soc 122:3843-3848

Milov AD, Tsvetkov YD, Formaggio F, Crisma M, Toniolo C, Raap J (2001a) The secondary structure of a membrane-modifying peptide in a supramolecular assembly studied by PELDOR and CW-ESR spectroscopies. J Am Chem Soc 123:3784-3789

Milov AD, Tsvetkov YD, Formaggio F, Crisma M, Toniolo M, Millhauser GL, Raap J (2001b) Self-assembling properties of a membrane-modifying lipopeptaibol in weakly polar solvents studied by CW ESR. J Phys Chem B 105:11206-11213

Milov AD, Samoilova RI, Tsvetkov YD, Gusev VA, Formaggio F, Crisma M, Toniolo C, Raap J (2002) Spatial distribution of spin-labeled trichogin GA IV in the gram-positive bacterial cell membrane determined from PELDOR data. Appl Magn Reson 23:81-95

Milov AD, Tsvetkov YD, Formaggio F, Crisma M, Toniolo C, Raap J (2003a) Self-assembling and membrane modifying properties of a lipopeptaibol studied by CW-ESR and PELDOR spectroscopies. J Pept Sci 9:690-700

Milov AD, Tsvetkov YD, Formaggio F, Oancea S, Toniolo C, Raap J (2003b) Aggregation of spin-labeled trichogin GA IV dimers: distance distribution between spin labels in frozen solutions by PELDOR data. J Phys Chem B 107:13719-13727

Milov AD, Tsvetkov YD, Formaggio F, Oancea S, Toniolo C, Raap J (2004) Solvent effect on the distance distribution between spin labels in aggregated spin-labeled trichogin GA IV dimer peptides as studied by pulsed electron-electron double resonance. Phys Chem Chem Phys 6:3596-3603

Milov AD, Erilov DA, Salnikov ES, Tsvetkov YD, Formaggio F, Toniolo C, Raap J (2005a) Structure and spatial distribution of the spin-labelled lipopeptide trichogin GA IV in a phospholipid 
membrane studied by pulsed electron-electron double resonance (PELDOR). Phys Chem Chem Phys 7:1794-1799

Milov AD, Samoilova RI, Tsvetkov YD, Formaggio F, Toniolo C, Raap R (2005b) Membrane-peptide interaction studied by PELDOR and CW ESR: Peptide conformations and cholesterol effect on the spatial peptide distribution in the membrane. Appl Magn Reson 29:703-716

Milov AD, Samoilova MI, Tsvetkov YD, Jost M, Peggion C, Formaggio F, Crisma M, Toniolo C, Handgraaf JW, Raap J (2007) Supramolecular structure of self-assembling alamethicin analog studied by ESR and PELDOR. Chem Biodivers 4:1275-1298

Milov AD, Samoilova RI, Tsvetkov YD, De Zotti M, Toniolo C, Raap J (2008) PELDOR conformational analysis of bis-labeled alamethicin aggregated in phospholipid vesicles. J Phys Chem B 112:13469-13472

Milov AD, Samoilova RI, Tsvetkov YD, De Zotti M, Formaggio F, Toniolo C, Handgraaf JW, Raap J (2009) Structure of selfaggregated alamethicin in ePC membranes detected by pulsed electron-electron double resonance and electron spin echo envelope modulation spectroscopies. Biophys J 96:3197-3209

Monaco V, Formaggio F, Crisma M, Toniolo C, Hanson P, Millhauser G, George G, Deschamps JR, Flippen-Anderson JL (1999a) Determining the occurrence of a 310 -helix and an $\alpha$-helix in two different segments of a lipopeptaibol antibiotic using TOAC, a nitroxide spin-labeled $C^{\alpha}$-tetrasubstituted $\alpha$-aminoacid. Bioorg Med Chem 7:119-131

Monaco V, Formaggio F, Crisma M, Toniolo C, Hanson P, Millhauser GL (1999b) Orientation and immersion depth of a helical lipopeptaibol in membranes using TOAC as an ESR probe. Biopolymers 50:239-253

Moraes LG, Fázio MA, Vieira RF, Nakaie CR, Miranda MT, Schreier S, Daffre S, Miranda A (2007) Conformational and functional studies of gomesin analogues by $\mathrm{CD}, \mathrm{EPR}$ and fluorescence spectroscopies. Biochim Biophys Acta 1768:52-58

Nakaie CR, Goissis G, Schreier S, Paiva ACM (1981) pH dependence of EPR spectra of nitroxides containing ionizable groups. Braz $\mathrm{J}$ Med Biol Res 14:173-180

Nakaie CR, Schreier S, Paiva ACM (1983) Synthesis and conformational properties of spin-labeled angiotensin derivatives. Biochim Biophys Acta 742:63-71

Nakaie CR, Marchetto R, Schreier S, Paiva ACM (1988) Synthetic and physicochemical studies of benzhydrylamine-resin with different substitution levels: implications for the solid phase peptide synthesis. In: Marshall GR (ed) Peptides. Structure and function. ESCOM, Leiden, pp 249-251

Nakaie CR, Marchetto R, Schreier S, Paiva ACM (1990) High-loading effect in solid phase peptide synthesis: swelling and ESR approaches. In: Rivier JE, Marshall GR (eds) Peptides. Chemistry, structure and biology. ESCOM, Leiden, pp 1022-1023

Nakaie CR, Barbosa SR, Vieira RF, Fernandez RM, Cilli EM, Castrucci AM, Visconti MA, Ito AS, Lamy-Freund MT (2001) Comparative EPR and fluorescence conformational studies of fully active spin-labeled melanotropic peptides. FEBS Lett 497:103-107

Nakaie CR, Silva EG, Cilli EM, Marchetto R, Schreier S, Paiva TB, Paiva AC (2002) Synthesis and pharmacological properties of TOAC-labeled angiotensin and bradykinin analogs. Peptides 23:65-70

Nakaie CR, Malavolta L, Schreier S, Trovatti E, Marchetto R (2006) Direct electron paramagnetic resonance monitoring of the peptide synthesis coupling reaction in polymeric support. Polymer 47:4531-4536

Nesmelov YE, Karim CB, Song L, Fajer PG, Thomas DD (2007) Rotational dynamics of phospholamban determined by multifrequency electron paramagnetic resonance. Biophys J 93:28052812
Newstadt JP, Mayo DJ, Inbaraj JJ, Subbaraman N, Lorigan GA (2009) Determining the helical tilt of membrane peptides using electron paramagnetic resonance spectroscopy. J Magn Reson 198:1-7

Ohnishi S, McConnell HM (1965) Interaction of the radical ion of chlorpromazine with deoxyribonucleic acid. J Am Chem Soc 87:2293-2299

Oliveira E, Cilli EM, Miranda A, Jubilut GN, Albericio F, Andreu D, Paiva ACM, Schreier S, Tominaga M, Nakaie CR (2002) Monitoring the chemical assembly of a transmembrane bradykinin receptor fragment: correlation between resin solvation, peptide chain mobility, and rate of coupling. Eur J Org Chem 21:3686-3694

Peggion C, Jost M, Baldini C, Formaggio F, Toniolo C (2007a) Total syntheses in solution of TOAC-labelled alamethicin F50/5 analogues. Chem Biodivers 4:1183-1199

Peggion C, Jost M, De Borggraeve WM, Crisma M, Formaggio F, Toniolo C (2007b) Conformational analysis of TOAC-labelled alamethicin F50/5 analogues. Chem Biodivers 4:1256-1268

Pertinhez TA, Nakaie CR, Carvalho RSH, Paiva ACM, Tabak A, Toma F, Schreier S (1995) Conformational changes upon binding of a receptor loop to lipid structures: possible role in signal transduction. FEBS Lett 375:239-242

Pertinhez TA, Nakaie CR, Paiva ACM, Schreier S (1997) Spin-labeled extracellular loop from a seven-transmembrane helix receptor: studies in solution and interaction with model membranes. Biopolymers 42:821-829

Pertinhez-Sini TA, Nakaie CR, Carvalho RSH, Paiva ACM, Tabak M, Toma F, Schreier S (1994) Binding of peptide fragments from a seven helix membrane receptor to lipid bilayers and micelles. Braz J Med Biol Res 27:535-540

Péter A, Török R, Wright K, Wakselman M, Mazaleyrat JP (2003) Liquid chromatographic enantioseparation of spin-labelled $\beta$ amino acids. J Chromatogr A 1021:1-10

Petrlova J, Hong HS, Bricarello DA, Harishchandra G, Lorigan GA, Jin LW, Voss JC (2011) A differential association of Apolipoprotein $\mathrm{E}$ isoforms with the amyloid- $\beta$ oligomer in solution. Proteins 79:402-416

Pispisa B, Palleschi A, Stella L, Venanzi M, Toniolo C (1998) A nitroxide derivative as probe for conformational studies of short linear peptides in solution. Spectroscopic and molecular mechanics investigation. J Phys Chem B 102:7890-7898

Pispisa B, Stella L, Venanzi M, Palleschi A, Marchiori F, Polese A, Toniolo C (2000a) A spectroscopic and molecular mechanics investigation on a series of Aib-based linear peptides and a peptide template, both containing tryptophan and a nitroxide derivative as probes. Biopolymers 53:169-181

Pispisa B, Mazzuca C, Palleschi A, Stella L, Venanzi M, Formaggio F, Polese A, Toniolo C (2000b) Structural features of linear $(\alpha \mathrm{Me})$ Val-based peptides in solution by photophysical and theoretical conformational studies. Biopolymers 55:425-435

Pispisa B, Palleschi A, Stella L, Venanzi M, Mazzuca C, Formaggio F, Toniolo C, Broxterman QB (2002) Effects of helical distortions on the optical properties of amide $\mathrm{NH}$ infrared absorption in short peptides in solution. J Phys Chem B 106:5733-5738

Pispisa B, Mazzuca C, Palleschi A, Stella L, Venanzi M, Formaggio F, Toniolo C, Mazaleyrat JP, Wakselman M (2003a) Spectroscopic properties and conformational features of short linear peptides in solution: a fluorescence and molecular mechanics investigation. J Fluoresc 13:139-147

Pispisa B, Mazzuca C, Palleschi A, Stella L, Venanzi M, Wakselman M, Mazaleyrat JP, Rainaldi M, Formaggio F, Toniolo C (2003b) A combined spectroscopic and theoretical study of a series of conformationally restricted hexapeptides carrying a rigid binaphthyl-nitroxide donor-acceptor pair. Chem-Eur J 9:4084-4093

Polese A, Anderson DJ, Millhauser G, Formaggio F, Crisma M, Marchiori F, Toniolo C (1999) First interchain peptide interaction 
detected by ESR in fully synthetic, template-assisted, two-helix bundles. J Am Chem Soc 121:11071-11078

Rajca A, Kathirvelu V, Roy SK, Pink M, Rajca S, Sarkar S, Eaton SS, Eaton GR (2010) A spirocyclohexyl nitroxide amino acid spin label for pulsed EPR distance measurements. Chem-Eur J 16:5778-5782

Rassat A, Rey P (1967) Nitroxides. 23. Preparation of amino acid free radicals and their complex salts. Bull Soc Chim Fr 3:815-818

Ribeiro SCF, Schreier S, Nakaie CR, Cilli EM (2001) Effect of temperature on peptide chain aggregation: an EPR study of model peptidyl-resins. Tetrahedron Lett 42:3243-3246

Rozantsev EG (1970) Free nitroxyl radicals. Plenum, New York

Sackmann E, Träuble H (1972a) Studies of the crystalline-liquid phase transition of lipid model membranes. I. Use of spin labels and optical probes as indicators of the phase transition. J Am Chem Soc 94:4482-4491

Sackmann E, Träuble H (1972b) Studies of the crystalline-liquid crystalline phase transition of lipid model membranes. II. Analysis of electron spin resonance spectra of steroid labels incorporated into lipid membranes. J Am Chem Soc 94:4492-4498

Salnikov ES, Erilov DA, Milov AD, Tsvetkov YD, Peggion C, Formaggio F, Toniolo C, Raap J, Dzuba SA (2006) Location and aggregation of the spin-labeled peptide trichogin GA IV in a phospholipid membrane as revealed by pulsed EPR. Biophys J 91:1532-1540

Salnikov ES, De Zotti M, Formaggio F, Li X, Toniolo C, O'Neil JD, Raap J, Dzuba SA, Bechinger B (2009) Alamethicin topology in phospholipid membranes by oriented solid-state NMR and EPR spectroscopies: a comparison. J Phys Chem B 113:3034-3042

Santos EL, de Picoli SK, Sabatini RA, Martin RP, Fernandes L, Nardi DT, Malavolta L, Shimuta SI, Nakaie CR, Pesquero JB (2008) Functional assessment of angiotensin II and bradykinin analogues containing the paramagnetic amino acid TOAC. Int Immunopharmacol 8:293-299

Sartori E, Corvaja C, Oancea S, Formaggio F, Crisma M, Toniolo C (2005) Linear configuration of the spins of a stable trinitroxide radical based on a ternary helical peptide. Chem Phys Chem 6:1472-1475

Saviano M, Improta R, Benedetti E, Carrozzini B, Cascarano GL, Didierjean C, Toniolo C, Crisma M (2004) Benzophenone photophore flexibility and proximity: molecular and crystal-state structure of a Bpa containing trichogin dodecapeptide analogue. Chembiochem 5:541-544

Scheerer P, Park JH, Hildebrand PW, Kim YJ, Krauss N, Choe HW, Hofmann KP, Ernst OP (2008) Crystal structure of opsin in its G-protein-interacting conformation. Nature 455:497-502

Schreier S, Barbosa SR, Casallanovo F, Vieira RFF, Cilli EM, Paiva ACM, Nakaie CR (2004) Conformational basis for the biological activity of TOAC-labeled angiotensin II and bradykinin. EPR, circular dichroism and fluorescence studies. Biopolymers 74:389-402

Schreier-Muccillo S, Marsh D, Dugas H, Schneider H, Smith ICP (1973) A spin probe study of the influence of cholesterol on motion and orientation of phospholipids in oriented multibilayers and vesicles. Chem Phys Lipids 10:11-27

Schwyzer R (1995) 100 years lock-and-key concept: are peptide keys shaped and guided to their receptor by the target cell membrane? Biopolymers 37:5-16

Seelig J (1970) Spin label studies of oriented smectic liquid crystals (a model system for bilayer membranes). J Am Chem Soc 92:3881-3887

Shafer AM, Nakaie CR, Deupi X, Bennett VJ, Voss JC (2008) Characterization of a conformationally sensitive TOAC spinlabeled substance P. Peptides 29:1919-1929

Smythe ML, Nakaie CR, Marshall GR (1995) $\alpha$-Helical versus $3_{10}$-Helical conformation of alanine-based peptides in aqueous solution: an electron spinresonance investigation. J Am Chem Soc 117:10555-10562

Stewart JM, Young JD (1984) Solid phase peptide synthesis. Pierce Chemical, Rockford

Stone TJ, Buckman T, Nordio PL, McConnell HM (1965) Spin-labeled biomolecules. Proc Natl Acad Sci USA 54:1010-1017

Su X-C, Otting G (2010) Paramagnetic labeling of proteins and oligonucleotides for NMR. J Biomol NMR 46:101-112

Syryamina VN, Isaev NP, Peggion C, Formaggio F, Toniolo C, Raap J, Dzuba SA (2010) Small-amplitude backbone motions of the spin-labeled lipopeptide trichogin GA IV in a lipid membrane as revealed by electron spin echo. J Phys Chem B 114:1227712283

Teixeira LGD, Bersanetti PA, Schreier S, Carmona AK, Nakaie CR (2007) Analogues containing the paramagnetic amino acid TOAC as substrates for angiotensin I-converting enzyme. FEBS Lett 581:2411-2415

Thomas L, Scheidt HA, Bettio A, Huster D, Beck-Sickinger AG, Arnold K, Zschörnig O (2005) Membrane interaction of neuropeptide Y detected by EPR and NMR spectroscopy. Biochim Biophys Acta 1714:103-113

Thomas L, Scheidt HA, Bettio A, Beck-Sickinger AG, Huster D, Zschörnig O (2009) The interaction of neuropeptide Y with negatively charged and zwitterionic phospholipid membranes. Eur Biophys J 38:663-677

Todd AP, Cong JP, Levinthal F, Levinthal C, Hubbell WL (1989) Site-directed mutagenesis of colicin-E1 provides specific attachment sites for spin labels whose spectra are sensitive to local conformation. Proteins 6:294-305

Tominaga M, Barbosa SR, Poletti EF, Zukerman-Schpector J, Marchetto R, Schreier S, Paiva AC, Nakaie CR (2001) Fmoc-POAC: [(9-fluorenylmethyloxycarbonyl)-2,2,5,5-tetramethylpyrrolidine-N-oxyl-3-amino-4-carboxylic acid]: a novel protected spin-labeled $\beta$-amino acid for peptide and protein chemistry. Chem Pharm Bull 49:1027-1029

Toniolo C, Peggion C, Crisma M, Formaggio F, Shui X, Eggleston DS (1994) Structure determination of racemic trichogin A IV using centrosymmetric crystals. Nat Struct Biol 1:908-914

Toniolo C, Valente E, Formaggio F, Crisma M, Pilloni G, Corvaja C, Toffoletti A, Martinez GV, Hanson MP, Millhauser GL, George C, Flippen-Anderson JL (1995) Synthesis and conformational studies of peptides containing TOAC, a spin-labelled $\mathrm{C}^{\alpha, \alpha}$-disubstituted glycine. J Pept Sci 1:45-57

Toniolo C, Crisma M, Formaggio F (1998) TOAC, a nitroxide spin-labeled, achiral $\mathrm{C}^{\alpha}$-tetrasubstituted $\alpha$-amino acid, is an excellent tool in material science and biochemistry. Biopolymers 47:153-158

Toniolo C, Formaggio F, Crisma M, Mazaleyrat JP, Wakselman M, George C, Deschamps JR, Flippen-Anderson JL, Pispisa B, Venanzi M, Palleschi A (1999) First peptide-based system of rigid donor-rigid interchromophore spacer-rigid acceptor: a structural and photophysical study. Chem-Eur J 5:2254-2264

Toropov YV, Dzuba SA, Tsvetkov YD, Monaco V, Formaggio F, Crisma M, Toniolo C, Raap J (1998) Molecular dynamics and spatial distribution of TOAC spin-labelled peptaibols studied in glassy liquid by echo-detected EPR spectroscopy. Appl Magn Reson 15:237-246

Träuble H, Sackmann E (1972) Studies of the crystalline-liquid crystalline phase transition of lipid model membranes. 3 . Structure of a steroid-lecithin system below and above the lipid-phase transition. J Am Chem Soc 94:4499-4510

Van Eps N, Anderson LL, Kisselev OG, Baranski TJ, Hubbell WL, Marshall GR (2010) Electron paramagnetic resonance studies of functionally active, nitroxide spin-labeled peptide analogues of the C-terminus of a G-protein alpha subunit. Biochemistry 49:6877-6886 
Venanzi M, Valeri A, Palleschi A, Stella L, Moroder L, Formaggio F, Toniolo C, Pispisa B (2004) Structural properties and photophysical behavior of conformationally constrained hexapeptides functionalized with a new fluorescent analog of tryptophan and a nitroxide radical quencher. Biopolymers 75:128-139

Venanzi M, Gatto E, Bocchinfuso G, Palleschi A, Stella L, Formaggio F, Toniolo C (2006) Dynamics of formation of a helix-turn-helix structure in a membrane-active peptide: a time resolved spectroscopic study. Chembiochem 7:43-45

Victor KG, Cafiso DS (2001) Location and dynamics of basic peptides at the membrane interface: electron paramagnetic resonance of tetramethyl-piperidine- $N$-oxyl-4-amino-4-carboxylic acid-labeled peptides. Biophys J 81:2241-2250

Vieira RFF, Casallanovo F, Cilli EM, Paiva ACM, Schreier S, Nakaie CR (2002) Conformational studies of TOAC-labeled bradykinin analogues in model membranes. Lett Pept Sci 9:83-89

Vieira RFF, Casallanovo F, Marín N, Paiva AC, Schreier S, Nakaie CR (2009) Conformational properties of angiotensin II and its active and inactive TOAC-labeled analogs in the presence of micelles. Electron paramagnetic resonance, fluorescence, and circular dichroism studies. Biopolymers 92:525-537

Wilson EK (2000) A new spin: peptide probes. Chem Eng News 78:54-59

Wright K, Crisma M, Toniolo C, Török R, Péter A, Wakselman M, Mazaleyrat JP (2003a) 4-Amino-1-oxyl-2,2,6,6-tetramethylpiperidine-3-carboxylic acid ( $\beta$-TOAC), the first spin-labelled, cyclic, chiral $\beta$-amino acid resolved in an enantiomerically pure state. Tetrahedron Lett 44:3381-3384

Wright K, Formaggio F, Toniolo C, Török R, Péter A, Wakselman A, Mazaleyrat JP (2003b) First access to the spin-labelled $\beta$-amino acid POAC in an enantiopure state by resolution through its binaphthyl esters. Tetrahedron Lett 44:4183-4186

Wright K, de Castries A, Sarciaux M, Formaggio F, Toniolo C, Toffoletti A, Wakselman M, Mazaleyrat JP (2005) Synthesis and spectroscopic characterization of enantiopure protected trans-4amino-1-oxyl-2,2,6,6-tetramethyl piperidine-3-carboxylic acid (trans $\beta$-TOAC). Tetrahedron Lett 46:5573-5576

Wright K, Sarciaux M, de Castries A, Wakselman M, Mazaleyrat JP, Toffoletti A, Corvaja C, Crisma M, Peggion C, Formaggio F, Toniolo C (2007) Synthesis of enantiomerically pure cis- and trans-4-amino-1-oxyl-2,2,6,6-tetramethylpiperidine-3-carboxylic acid: a spin-labelled, cyclic, chiral $\beta$-amino acid, and $3 \mathrm{D}$ structural analysis of a doubly spin-labelled $\beta$-hexapeptide. Eur J Org Chem 2007:3133-3144

Wright K, Dutot L, Wakselman M, Mazaleyrat JP, Crisma M, Formaggio F, Toniolo C (2008) Synthesis, resolution and assignment of absolute configuration of trans 3-amino-1-oxyl-2,2,5,5tetramethylpyrrolidine-4-carboxylic acid (POAC), a cyclic, spinlabelled beta-amino acid. Tetrahedron 64:4416-4426

Wright K, Wakselman M, Mazaleyrat JP, Franco L, Toffoletti A, Formaggio F, Toniolo C (2010) Synthesis and conformational characterisation of hexameric $\beta$-peptide foldamers by using double POAC spin labelling and cw-EPR. Chem-Eur J 16:11160-11166

Zasloff M (2002) Antimicrobial peptides of multicellular organisms. Nature 415:389-395

Zerbetto M, Carlotto S, Polimeno A, Corvaja C, Franco L, Toniolo C, Formaggio F, Barone V, Cimino P (2007) Ab initio modeling of CW-ESR spectra of the double spin-labeled peptide Fmoc(Aib-Aib-TOAC) $)_{2}$-Aib-OMe in acetonitrile. J Phys Chem B 111:2668-2674

Zhang Z, Remmer HA, Thomas DD, Karim CB (2007) Backbone dynamics determined by electron paramagnetic resonance to optimize solid-phase peptide synthesis of TOAC-labeled phospholamban. Biopolymers 88:29-35

Zhang Z, Xi X, Scholes CP, Karim CB (2008) Rotational dynamics of HIV-1 nucleocapsid protein NCp7 as probed by a spin label attached by peptide synthesis. Biopolymers 89:11251135 